\title{
Microbial Carbonic Anhydrases in Biomimetic Carbon Sequestration for Mitigating Global Warming: Prospects and Perspectives
}

\author{
Himadri Bose and Tulasi Satyanarayana * \\ Department of Microbiology, University of Delhi, New Delhi, India
}

All the leading cities in the world are slowly becoming inhospitable for human life with global warming playing havoc with the living conditions. Biomineralization of carbon dioxide using carbonic anhydrase (CA) is one of the most economical methods for mitigating global warming. The burning of fossil fuels results in the emission of large quantities of flue gas. The temperature of flue gas is quite high. Alkaline conditions are necessary for $\mathrm{CaCO}_{3}$ precipitation in the mineralization process. In order to use CAs

OPEN ACCESS

Edited by:

Rajesh K. Sani,

South Dakota School of Mines and Technology, United States

Reviewed by: Navanietha Krishnaraj Rathinam, National Institute of Technology,

Durgapur, India

Saurabh Dhiman,

South Dakota School of Mines and Technology, United States

${ }^{*}$ Correspondence:

Tulasi Satyanarayana

tsnarayana@gmail.com

Specialty section: This article was submitted to Microbiotechnology, Ecotoxicology and Bioremediation,

a section of the journal

Frontiers in Microbiology

Received: 28 April 2017 Accepted: 08 August 2017

Published: 25 August 2017

Citation:

Bose H and Satyanarayana T (2017)

Microbial Carbonic Anhydrases in Biomimetic Carbon Sequestration for Mitigating Global Warming: Prospects and Perspectives.

Front. Microbiol. 8:1615. doi: 10.3389/fmicb.2017.01615 for biomimetic carbon sequestration, thermo-alkali-stable CAs are, therefore, essential. CAs must be stable in the presence of various flue gas contaminants too. The extreme environments on earth harbor a variety of polyextremophilic microbes that are rich sources of thermo-alkali-stable CAs. CAs are the fastest among the known enzymes, which are of six basic types with no apparent sequence homology, thus represent an elegant example of convergent evolution. The current review focuses on the utility of thermo-alkali-stable CAs in biomineralization based strategies. A variety of roles that CAs play in various living organisms, the use of CA inhibitors as drug targets and strategies for overproduction of CAs to meet the demand are also briefly discussed.

Keywords: global warming, polyextremophilic microbes, thermo-alkali-stable, carbonic anhydrase, biomineralization, CA inhibitors

\section{INTRODUCTION}

In the early Eighteenth century, industrial revolution took the world by storm. This led to large scale manufacture, which at that time proved to be a major economic boost world over. In the last 300 years, there has been a marked transformation in human life. Due to improved farming practices, food production increased. This along with technological advances in health, communication and transport sectors paved the way toward modern age for human civilization. This modernization led to a heavy toll on "mother nature" (Shakun et al., 2012).

The concentrations of greenhouse gases are increasing day by day mainly due to anthropogenic activities, of them about two-thirds is contributed by fossil fuels. The burning of fossil fuels results in the emission of large quantities of flue gas that contains $\sim 71 \% \mathrm{~N}_{2}, 14 \%$ $\mathrm{CO}_{2}, 1-2 \%$ hydrocarbons, carbon monoxide, $\mathrm{NO}_{\mathrm{x}}$, and minor amounts of $\mathrm{SO}_{\mathrm{x}}$ (Perry and Gee, 1995). According to IPCC, among all the greenhouse gases, $\mathrm{CO}_{2}$ is emitted most (65\% from fossil fuels and $11 \%$ from forestry). Other gases such as methane (16\%), nitrous oxide $(6 \%)$, and fluorinated gases $(2 \%)$ are emitted in smaller amounts by anthropogenic activities (IPCC, 2014). Cumulative carbon emissions from different sectors have increased by 
about $40 \%$ since 1970s. The concentrations of hazardous gases such as NOx, SOx and methane are well beyond their threshold in many cities all over the world, thus, the Air Quality Index (AQI) is declining (IPCC, 2000). $\mathrm{CO}_{2}$ levels in the atmosphere have surged past the threshold of $400 \mathrm{ppm}$ and it may not climb down for generations. This 400 ppm benchmark was broken first time in the recorded history last year. According to World Meteorological Organization (WMO), 2016 would be the first full year to exceed the mark (NOAA, 2016). As per the latest measurement by NOAA in April 2017, the concentration of $\mathrm{CO}_{2}$ at present is 406.17 ppm (NOAA, 2017). Some of the isolated places (Arctic regions) have already breached this mark in the past few years as recorded in Mouna Loa Observatory in 2013 (IPCC, 2013). Emission Database for Global Atmospheric Research stated that global emission of $\mathrm{CO}_{2}$ has increased by $48 \%$ in the last two decades (http://edgar.jrc.ec. europa.eu/ overview.php?v) ${ }^{1}$. The increase in GHG emissions has led to increase in earth's surface temperature by about $2{ }^{\circ} \mathrm{C}$ from pre-industrial times (IPCC, 2000). These conditions have also led to widespread natural calamities and affected the environment adversely. An increase in warm temperature extremes and decrease in cold temperature extremes have been noted in the past few years. This has also led to an impact on the precipitation patterns around the world and disturbed the water cycle. Agricultural production has been affected due to adverse climatic changes. There has been a reduction in crop yields leading to increase in food prices, food shortage and insecurity (Adams et al., 1998). These climatic hazards are affecting the lives of people round the world particularly those who are living below the poverty line. Many freshwater, marine and terrestrial species are already on the verge of extinction. A change in the distribution and interaction pattern has been observed in many freshwater and marine phytoplanktons. According to IPCC, the period from 1983 to 2012 were the warmest years (IPCC, 2014).

Air pollution causes various respiratory and cardiac diseases. Tiny particles produced by vehicular engines and industry worsen heart and brain related disorders and increase the risk of stroke. Global warming is taking the earth toward peril and it is essential to tackle this catastrophe for our survival. It is next to impossible for developing and under developed nations to control large scale $\mathrm{CO}_{2}$ emissions. Nevertheless, global warming has to be mitigated. Scientific and global consensus on global warming and climate change has brought the world powers together in order to hunt for new technologies for mitigating the global warming (Kheshgi et al., 2012).

The year 2015 ushered in an era of optimism and action with Paris climate change agreement. It also marks a new era of climate change reality with record levels of high greenhouse gases. In order to tackle increasing carbon emissions, carbon trading and taxation have been implemented by various countries (Princiotta, 2007). The progress made in developing carbon capture technologies has been reviewed from time to time (Boone et al., 2013; Frost and McKenna, 2013). IPCC has also published a wholesome review on different CCS technologies

\footnotetext{
${ }^{1}$ Emission database for global atmospheric research EDGAR, European Commission. Available online at: http://edgar.jrc.ec.europa.eu/ (Accessed February 27, 2017).
}

providing a precious input for policy makers and researchers in developing schemes for reducing GHG emissions (IPCC, 2000, 2013, 2014). Some reviews have also outlined various holistic approaches for carbon capture and also described methods for mitigating global warming. This review discusses biomimetic approach for mitigation of global warming with a special focus on utilizing nature's own catalyst, carbonic anhydrase (CA), as the biomimetic carbon sequestering agent.

\section{APPROACHES FOR MITIGATING GLOBAL WARMING}

Countries round the world have initiated a number of measures to counter the alarming rise of $\mathrm{CO}_{2}$ in the environment which includes use of low carbon fuels (nuclear power, natural gas etc.), increasing the use of renewal energy and applying geo-engineering approaches [afforestation and reforestation, and $\mathrm{CO}_{2}$ capture, storage and utilization (CCSU)]. All these approaches have their own set of merits and demerits. It is impossible to curtail the carbon emissions by using only one of the measures. The major drawback of these measures is very high capital investments as non-conventional energy sources are associated with high cost and at times they are not user friendly as well (Faridi and Satyanarayana, 2015). Among them, CCSU can reduce the carbon emissions by $80-85 \%$ by capturing $\mathrm{CO}_{2}$ directly from power plants and energy intensive processes such as cement industries, which are described in detail (Boot-Handford et al., 2014; Leung et al., 2014) in the following sections.

\section{CARBON CAPTURE AND STORAGE (CCS) $\mathrm{CO}_{2}$ Capture}

$\mathrm{CO}_{2}$ emissions are captured and separated from flue gas, transported via huge pipelines and stored permanently deep underground or reutilized for various applications. Various approaches have been designed for efficient $\mathrm{CO}_{2}$ capture. These approaches are basically divided into three phases:

- Pre-combustion $\mathrm{CO}_{2}$ capture

- Post-combustion $\mathrm{CO}_{2}$ capture

- Oxyfuel combustion

In pre-combustion $\mathrm{CO}_{2}$ capture, the fuel is treated initially before combustion as in the case of coal or natural gas. Coal undergoes gasification process resulting in the formation of syngas $(\mathrm{CO}+$ $\mathrm{H}_{2}$ ). The reaction takes place in low $\mathrm{O}_{2}$ environment. Further, this syngas (which is free from pollutants) undergoes water gas shift reaction to form $\mathrm{CO}_{2}$ and $\mathrm{H}_{2} \mathrm{O}$. This technique can be applied in power plants using coal as a fuel source, but it incurs an efficiency loss of $7-8 \%$. Natural gas containing mainly methane $\left(\mathrm{CH}_{4}\right)$ can be converted to syngas and rest of the procedure is same like that of coal (Olajire, 2010). In post-combustion $\mathrm{CO}_{2}$ capture, carbon is captured from flue gas generated after combustion. This technique has been considered useful for the existing power plants and approved in small scale with a $\mathrm{CO}_{2}$ recovery rate of $800 \mathrm{t}$ /day (Wall, 2007). Oxyfuel combustion uses oxygen in place of air for combustion. This substantially reduces the NOx load in the exhaust gas. Hence 
the remaining gas only contains $\mathrm{SO}_{2}$, water and $\mathrm{CO}_{2} . \mathrm{SO}_{2}$ can be easily removed by precipitation or desulphurization leading to about $80-98 \%$ recovery of $\mathrm{CO}_{2}$. This process requires large quantities of pure $\mathrm{O}_{2}$ that increases overall cost of the process. The presence of a large amount of $\mathrm{SO}_{2}$ in flue gas would cause corrosion problems (Buhre et al., 2005; Pfaff and Kather, 2009).

$\mathrm{CO}_{2}$ separation from flue gas is carried out by various ways such as absorption [liquid sorbents such as monoethanolamine (MEA), diethanolamine (DEA) used to separate $\mathrm{CO}_{2}$ ], adsorption (solid adsorbent such as zeolite, activated carbon are used to bind $\mathrm{CO}_{2}$ on its surface), chemical looping combustion (metal oxide is used as oxygen carrier for combustion), membrane separation (allows only $\mathrm{CO}_{2}$ to pass through while trapping other components), hydrate based separation (flue gas exposed to high pressure of water, leading to formation of hydrates and $\mathrm{CO}_{2}$ gets trapped within them) and cryogenic distillation (distillation at low temperature and high pressure), thereby separating the solidified $\mathrm{CO}_{2}$ (Aaron and Tsouris, 2005; Knudsen et al., 2009; Bhown and Freeman, 2011).

\section{$\mathrm{CO}_{2}$ Transport}

Large pipelines are used in transport of $\mathrm{CO}_{2}$ to storage sites or to facilities where it can be reutilized. Pipelines are the most efficient and viable method of $\mathrm{CO}_{2}$ transport to long distances. Various factors have to be considered for the proper transport of $\mathrm{CO}_{2}$. Mass/volume ratio is optimized by transporting the $\mathrm{CO}_{2}$ in supercritical conditions (i.e., pressure is maintained at $72.1 \mathrm{~atm}$ and temperature around $32^{\circ} \mathrm{C}$; Svensson et al., 2004). Impurities in the $\mathrm{CO}_{2}$ stream leads to alteration in pressure and temperature, thus, impurities must be taken care of. The formation of carbonic acid due to the presence of water leads to corrosion of the pipelines, which are mostly made of carbon steel. Large integrated network of pipelines are needed for a commercial CCS project (Aspelund et al., 2006). These large networks will help in decreasing overall length of the pipeline by $25 \%$, thereby reducing the associated cost. The cost of transport also depends on the regional and economic conditions of a country. A cost analysis in China showed that for a mass flow of $4,000 \mathrm{t} \mathrm{CO}_{2}$ /day, the use of ship tankers will cost $7.48 \mathrm{USD} /$ tonne $\mathrm{CO}_{2}$ as compared to $12.64 \mathrm{USD} /$ tonne $\mathrm{CO}_{2}$ for railway tankers and $7.05 \mathrm{USD} /$ tonne $\mathrm{CO}_{2}$ for $300 \mathrm{~km}$ pipelines. Periodical monitoring and assessment of the pipelines is needed for efficient and regular transport (Gao et al., 2014).

\section{$\mathrm{CO}_{2}$ Storage: Geological Storage}

Carbon dioxide can be stored into rock pores $800 \mathrm{~m}$ below the surface in abandoned deep saline aquifers and oil or gas reservoirs. This is called geological carbon sequestration (Orr, 2009). The choice of a good sequestering site is always useful for long term carbon storage. Porous and permeable surfaces having non-potable ground water or the sites having sedimentary rock formations made of such chemicals (e.g., calcium) can react with $\mathrm{CO}_{2}$ leading to more stable formations, which are preferable sites for storage (Benson et al., 2005). The first large scale $\mathrm{CO}_{2}$ sequestration project which started in 1996 was called Sleipner, located in the North Sea where Norway's Statoil Hydro strips carbon dioxide from natural gas with amine solvents and disposed of carbon dioxide in a deep saline aquifer. $\mathrm{CO}_{2}$ can be transported in high pressures into nearly depleted oil/gas wells in order to extract the residual oil and gases, while the injected $\mathrm{CO}_{2}$ remains stored (enhanced oil recovery). $\mathrm{CO}_{2}$ can be injected into deep coal beds to release methane which is trapped in porous structure of coal seams $\left(\mathrm{CO}_{2}\right.$-enhanced coal bed mehane). Deep aquifers at a depth of 700-1,000 $\mathrm{m}$ below ground level contain high salinity brines, which can be used to store injected $\mathrm{CO}_{2}$ captured from CCS process (Hart and Gnanendran, 2009).

\section{Deep Ocean Storage}

Oceans are the natural sinks for $\mathrm{CO}_{2}$ and it can be injected into the ocean by direct injection and ocean fertilization. Oceans can take up about 2 billion metric tons of $\mathrm{CO}_{2}$ per annum, the amount of carbon that would double the load in the atmosphere and would increase the concentration in the deep ocean by only $2 \%$. At depths of more than $3 \mathrm{~km}, \mathrm{CO}_{2}$ gets liquefied and can easily sink to the sea floor due to its higher density than the adjoining seawater and can be stored there for a long time. Beside these, three other mechanisms have also been proposed for $\mathrm{CO}_{2}$ storage. Physical trapping of $\mathrm{CO}_{2}$ using immobilization in a gaseous or supercritical phase in geological formations causes its immobilization that leads to either static trapping in structural traps or residual gas trapping in porous structure. Chemical trapping in formation fluids (water/hydrocarbon) either by ionic trapping or by dissolution, where $\mathrm{CO}_{2}$ can react chemically with minerals after dissolution to form mineral trappings or it can get adsorbed on mineral surface (adsorption trapping). Hydrodynamic trapping through the upward migration of $\mathrm{CO}_{2}$ at very slow speed results in its trapping into the intermediate layers. In this manner, large quantities of $\mathrm{CO}_{2}$ can be stored (Benson et al., 2005). Polymer microcapsules composed of liquid carbonate cores, which have high surface area for controlled uptake of $\mathrm{CO}_{2}$, have been utilized for large scale carbon capture process. Higher adsorption of carbon dioxide was achieved and these microcapsules were found to be stable under typical industrial operating conditions (Vericella et al., 2015).

\section{Demerits of CCS Technology}

Although, CCS approaches are quite efficient, they still have certain implications. First of all the cost of the overall process is quite high. It has been estimated that CCS will lead to a rise in power tariff by about $10 \%$ in US alone. It also requires a large amount of energy as it consumes 25 percent of the power plant's output capacity. The use of MEA in capture methods may lead to corrosion, evaporative losses, generation of toxic degradation products, and may require significant energy to remove $\mathrm{CO}_{2}$ during sorbent regeneration (Nielsen et al., 2012; Reynolds et al., 2012; Da Silva and Booth, 2013). There are some other disadvantages associated with the post-combustion amine capture method. The equipment will be very large as compared to the small size of a coal-fired power plant. Large volumes of solvents are needed. Regeneration of solvent by heating produces toxic byproducts, which should be scrubbed and eliminated. This 
process also utilizes large volumes of water (Herzog, 1998). In this approach, the energy utilization increases by about $15-25 \%$. During transport and storage of $\mathrm{CO}_{2}$, there is a risk of leakage. Direct injection of $\mathrm{CO}_{2}$ will lead to the acidification of deep ocean (Dutreuil et al., 2009) which may cause disastrous effects on marine ecosystem. That's why only geological storage of $\mathrm{CO}_{2}$ into deep saline aquifers and unused mines is somewhat acceptable (Shahbazi and Nasab, 2016). The CCS technology is still in pilot scale and a large scale commercialization is yet to be undertaken. Way back in 2010, Tsouris et al. (2010) pointed high costs associated with CCS technology and urged the world to direct its energies on alternative energy technology. It is also true that in near future it will be very difficult to move away from fossil fuels as energy source. Biomineralization of $\mathrm{CO}_{2}$ using metal oxides $(\mathrm{MgO}$ and $\mathrm{CaO}$ ) with the help of ubiquitous biocatalyst carbonic anhydrase (CA) provides a cost effective and environmentally benign solution for mitigation of global warming, which will be discussed in detail in the ensuing sections.

\section{Mineralization of Atmospheric Carbon}

This process mimics the mineralization process occurring in nature which is responsible for the presence of huge amounts of limestone on the surface of Earth. This is called silicate weathering. It traps the atmospheric carbon by reacting with large limestone rocks such as wollastonite $\left(\mathrm{CaSiO}_{3}\right)$, serpentine $\left(\mathrm{Mg}_{3} \mathrm{Si}_{2} \mathrm{O}_{5}(\mathrm{OH})_{4}\right)$ and olivine $\left(\mathrm{Mg}_{2} \mathrm{SiO}_{4}\right)$ (Huijgen et al., 2007; Santos et al., 2007). This process occurs in both salt and fresh waters as $\mathrm{CO}_{2}$ gets dissolved in water easily and there exists equilibrium between $\mathrm{CO}_{2}, \mathrm{HCO}_{3}^{-}$, and $\mathrm{CO}_{3}^{2-}$. The set of reactions involved in $\mathrm{CO}_{2}$ mineralization is outlined below (Farrell, 2011):

Gaseous $\mathrm{CO}_{2}$ dissolves quickly in water and produces a loosely hydrated aqueous form (1).

$$
\mathrm{CO}_{2}(\mathrm{~g}) \rightarrow \mathrm{CO}_{2}(\mathrm{aq})
$$

Then carbonic acid is formed when aqueous $\mathrm{CO}_{2}$ reacts with water (2).

$$
\mathrm{CO}_{2}(\mathrm{aq})+\mathrm{OH}^{-} \rightarrow \mathrm{H}_{2} \mathrm{CO}_{3}
$$

In the 2nd step, carbonic acid breaks down into carbonate and bicarbonate ions $[(3),(4)]$

$$
\begin{aligned}
\mathrm{H}_{2} \mathrm{CO}_{3} & \rightarrow \mathrm{wHCO}_{3}^{-}+\mathrm{H}^{+} \\
\mathrm{HCO}_{3}^{-}+\mathrm{OH}^{-} & \rightarrow \mathrm{CO}_{3}^{2-}+\mathrm{H}_{2} \mathrm{O}
\end{aligned}
$$

The presence of metal ions such as $\mathrm{Ca}^{2+}, \mathrm{Mg}^{2+}$, and $\mathrm{F}^{e 2+}$ drives the precipitation of carbonate into mineral carbonates as depicted below (5):

$$
\begin{aligned}
& \mathrm{CO}_{3}^{2-}+\mathrm{Ca}^{2+} \rightarrow \mathrm{CaCO}_{3} \downarrow \text { (calcite) } \\
& \mathrm{CO}_{3}^{2-}+\mathrm{Mg}^{2+} \rightarrow \mathrm{MgCO}_{3} \downarrow \text { (magnesite) } \\
& \mathrm{CO}_{3}^{2-}+\mathrm{Ca}^{2+}+\mathrm{Mg}^{2+} \rightarrow \mathrm{CaMg}\left(\mathrm{CO}_{3}\right)_{2} \downarrow \text { (dolomite) } \\
& \mathrm{CO}_{3}^{2-}+\mathrm{Fe}^{2+} \rightarrow \mathrm{FeCO}_{3} \downarrow \text { (siderite) }
\end{aligned}
$$

This process is $\mathrm{pH}$ dependent. At $\mathrm{pH}$ below 8.0, reaction 2 becomes insignificant as $\mathrm{OH}^{-}$ions are absent. Between $\mathrm{pH}$ 8.0 and 10.0, both the reactions ( 2 and 3 ) occur, and above $\mathrm{pH} 10$, reaction 2 occurs mainly. Due to abundant supply of
$\mathrm{OH}^{-}$at alkaline $\mathrm{pH}$, mainly $\mathrm{HCO}_{3}^{-}$(bicarbonate) and $\mathrm{CO}_{3}^{-}$ form leading to $\mathrm{CaCO}_{3}$ precipitation. Also at acidic $\mathrm{pH}$, the solubility of carbonate increases. In order to increase carbonate precipitation, it is necessary to make the environment alkaline. Mineral carbonation is being studied at length for its utility in biomineralization of $\mathrm{CO}_{2}$ from flue gas. Some pilot scale studies have already been undertaken to demonstrate the viability of the process (Reddy et al., 2010).

This technique has several advantages over other sequestration based approaches:

1. This process is an environmentally benign and one of the most effective techniques of carbon sequestration, and carbonates produced naturally via mineralization of $\mathrm{CO}_{2}$ can remain stable for centuries. This process is free from complexities and many researchers have already outlined this process in minute details, hence, easily adaptable (Seifritz, 1990; Druckenmiller and Maroto-Valer, 2005; Liu et al., 2005; Stolaroff et al., 2005; Mirjafari et al., 2007; Favre et al., 2009).

2. Raw materials for mineralization of $\mathrm{CO}_{2}$ are in abundance. These minerals comprise a huge $\mathrm{CO}_{2}$ reservoir having carbon equivalent to about $150,000 \times 10$ metric tons of $\mathrm{CO}_{2}$. Metal oxides such as $\mathrm{MgO}$ and $\mathrm{CaO}$ are emitted from the industries as hazardous wastes in the form of fly ash (Soong et al., 2006). Mineral carbonation using such wastes will allow their reutilization in sequestering $\mathrm{CO}_{2}$ (Stolaroff et al., 2005). Fly ash was used for mineral carbonation in USA and concentration of $\mathrm{CO}_{2}$ reduced from 13.0 to $9.6 \%$ and $\mathrm{SO}_{2}$ concentration drastically decreased from $107.8 \mathrm{ppm}$ to $15.1 \mathrm{ppm}$ within 2 min (Reddy et al., 2010).

3. Mineral carbonates formed after sequestration will also provide industrially valuable and useful byproducts such as cements, chemicals, fillers for paper making, white paints, and other construction materials. These mineral carbonates are also used in manufacturing calcium supplements, antacids and tableting the excipient for medical usage as well as remediation of waste feed stocks (Ciullo, 1996). Pure silica with a desirable particle size can be used as a material in the construction, plastics, electronics, and glass industries.

4. The process is economically viable, since it eliminates the large scale and energy-intensive process of solvent capture of $\mathrm{CO}_{2}$ from industrial wastes. This process does not require the transportation of supercritical $\mathrm{CO}_{2}$ into deep underground.

Despite being very effective, it has certain limitations. The process is very slow in ambient conditions (Haywood et al., 2001). According to the study of kinetics of calcite precipitation by Dreybodt et al. (1997), except at high $\mathrm{pH}$, the formation of $\mathrm{HCO}_{3}^{-}$ (bicarbonate) is the rate limiting step. Equilibrium constants for reactions (2) and (3) are $2.6 \times 10^{-3}$ and $1.7 \times 10^{-4}$, respectively (Mirjafari et al., 2007). The rate of reaction (3) and (4) is being virtually diffusion controlled and very rapid. If $\mathrm{CO}_{2}$ hydration rate could be enhanced in some way or the other, then maximal amount of anthropogenic $\mathrm{CO}_{2}$ can be converted into mineral carbonates. As it is said that the "Nature has solution to every problem," we are endowed with a natural solution to the climate change problem in the form of carbonic anhydrase (CA). The CAs can speed up the entire mineralization process by catalyzing the hydration of dissolved $\mathrm{CO}_{2}$ into bicarbonate i.e., 
the reaction 2 at a faster rate (biomineralization). The addition of dolomite and K-feldspar to the soil can further enhance carbon sequestration in soil (Xiao et al., 2016). Use of CA as a potential biocatalyst has caught the attention of many researchers and much work has been done on exploring the possibilities of using this "Nature's own catalyst" for CCS (Farrell, 2011; Alvizo et al., 2014). Zinc(II) cyclen, which is a mimic of the enzyme carbonic anhydrase, was evaluated for its utilization in carbon capture process in rigorous conditions as that in industries and it was shown to be inhibited by bicarbonate accumulation (Floyd et al., 2013). There are some CA variants which can minimize bicarbonate inhibition by protecting the active site with a hydrophobic pocket. Hence, it is worthwhile to search for natural CA enzymes which can circumvent bicarbonate inhibition. Power et al. (2016) have successfully demonstrated the utility and efficiency of bovine carbonic anhydrase (BCA) and $\mathrm{CO}_{2}$-rich gas streams in the carbonation rate of brucite $\left[\mathrm{Mg}(\mathrm{OH})_{2}\right]$, which is a highly reactive mineral. Carbonation was affected by decrement in $\mathrm{CO}_{2}$ supply. In the following sections, the role of CA in CCS has been described in greater detail.

\section{Carbonic Anhydrase: Vital Cog in the Wheel of Life}

Carbonic anhydrases catalyze $\mathrm{CO}_{2}$ hydration and $\mathrm{HCO}_{3}^{-}$ dehydration, in almost all organisms. It (EC No. 4.2.1.1) is a zinc metalloenzyme which is used as a catalyst in living systems for the conversion of carbon dioxide to bicarbonates and vice-versa. It was the first zinc metalloenzyme to be discovered in living systems (Smith and Ferry, 2000). Zinc ion complex facilitates carbon dioxide hydration activity. In most of the organisms, CAs are required for rapid processes, particularly transport processes. For example, it is required for the removal of $\mathrm{CO}_{2}$ from lungs and for synthesis of eye secretions. CAs maintain optimum level of $\mathrm{CO}_{2}$ and $\mathrm{HCO}_{3}^{-}$in the body as they are utilized as substrate for many enzymatic reactions. It maintains acid-base balance in blood and helps in maintaining its physiological $\mathrm{pH}$ and also actively participates in ion transport and respiration. Mutations in CA genes can lead to osteoporosis and mental retardation. Carbonic anhydrase II (hCAII) is present in relatively high concentrations in red blood cells (Berg et al., 2002).

Initially the presence of the enzyme was found in the animal kingdom but later on CAs showed their signatures in all three living domains (Kaur et al., 2012; Di Fiore et al., 2015). This enzyme is either found intracellularly in cytoplasm or secreted outside (extracellular) associated with the periplasm and an essential component for survival of nearly all life forms. CAs are one of the fastest among the enzymes known having $\mathrm{k}_{\mathrm{cat}}$ in the order of $10^{6} \mathrm{~s}^{-1}$ and $\mathrm{k}_{\mathrm{cat}} / \mathrm{K}_{\mathrm{m}}$ in the order of $10^{8} \mathrm{M}^{-1} \mathrm{~s}^{-1}$. An "anhydrase" is defined as an enzyme that catalyzes the removal of a water molecule from a compound, and so it is this "reverse" reaction that gives carbonic anhydrase its name, because it removes a water molecule from carbonic acid (Smith et al., 1999). In plants, $\beta$-CAs have a role in photosynthesis in chloroplasts by raising the concentration of $\mathrm{CO}_{2}$ to enhance the carboxylation rate of ribulose 1, 5-bisphosphate carboxylase (RuBisCO) (Smith and Ferry, 2000). It functions in three modes: conversion of $\mathrm{CO}_{2}$ to bicarbonate (to be utilized by $\mathrm{RuBisCO}$ in $\mathrm{C}_{4}$ plants), conversion of bicarbonate into $\mathrm{CO}_{2}$ [for fixation by phosphoenol pyruvate carboxylase (PEPC)] and also aids in facilitated diffusion by rapid equilibration between $\mathrm{CO}_{2}$ and $\mathrm{HCO}_{3}^{-}$. It also provides bicarbonate, which is required for the metabolism in plants (Monti et al., 2013). Recently $\beta-\mathrm{CA}$ has been shown to play a role in the perception of salicylic acid in Arabidopsi thaliana, suggesting its requirement in defense response (Medina-Puche et al., 2017). Besides higher organisms, CAs are also required in lower organisms. In some of the heterotrophs such as Propionibacterium, CAs help in $\mathrm{CO}_{2}$ reduction during glycerol fermentation that results in the formation of oxaloacetate (Wood et al., 1941). In cyanobacteria and microalgae, CAs are involved in the $\mathrm{CO}_{2}$ concentrating mechanism (CCM), which helps the cells to photosynthesize in the absence of inorganic carbon and also due to decline in levels of $\mathrm{CO}_{2}$ in their surrounding environment (Badger and Price, 2003). CCM helps in maintenance of $\mathrm{CO}_{2}$ levels around the RuBisCo active centers thereby improving the efficiency of Calvin cycle. CAs have also been reported from facultative anaerobes such as Rhodospirillum rubrum (Gill et al., 1984). CAs supply the cellular transporters with $\mathrm{HCO}_{3}^{-}$by converting $\mathrm{CO}_{2}$ penetrating the cells into $\mathrm{HCO}_{3}^{-}$. Extracellular CA in alkaliphilic cyanobacteria plays a role in their survival in high alkaline conditions in alkaline soda lakes (Soltes-Rak et al., 1997; So et al., 1998; Kupriyanova et al., 2007, 2011). In Microcoleus and Rhabdoderma, CA doesn't allow $\mathrm{CO}_{2}$ to leak out from the cell by converting it into bicarbonate, thus preserving the intracellular $\mathrm{C}_{\mathrm{i}}$ pool for photoautotrophic assimilation. In Rhabdoderma, out of two CAs present, one is bound to photosystem II (PSII) of thylakoid membranes. It participates in the light photosynthetic reactions, regulating operation of the water oxidizing complex via its protection against excess of protons, similar to luminal CA of microalgae and higher plants (Shutova et al., 2008). $\mathrm{CA}$ in cyanobacterial thylakoid membranes supplies $\mathrm{CO}_{2}$ for photosynthesis in cyanobacteria. CA helps in the formation of oxaloacetic acid from carboxylase and phosphoenolpyruvate (PEP) carboxylase by providing bicarbonate which is utilized by pyruvate (Norici et al., 2002). This oxaloacetate is used for the synthesis of aspartate family of amino acids. Lysine production increases in elevated $\mathrm{CO}_{2}$ conditions owing to the action CA and PEP carboxylase (Puri and Satyanarayana, 2010). CA in carboxysomal shell of chemolithoautotrophic cyanobacterium Halothiobacillus neapolitanus (CsoS3) supplies the active sites of RuBisCO with high concentrations of $\mathrm{CO}_{2}$ necessary for RuBisCO activity and efficient carbon fixation (So et al., 2004). $\beta$-CA present in Escherichia coli is a major player in the cyanate degradation pathway of the organism. This type of CA has also been shown to play a role in pathogenesis of some bacteria such as Salmonella typhimurium (Valdivia and Falkow, 1997). In methanogens, CA plays an active role in acetate metabolism by converting the excess carbon dioxide produced into bicarbonates. It also helps in the conversion of acetate into methane. $\gamma$-class homologs of the CamH subclass are found in mitochondria, where it might have a role in the carbon transport system to increase the efficiency of photosynthetic carbon dioxide fixation (Tripp and Ferry, 2000). Hence CA and its classes play an 
important role in metabolic functions of all life forms. Life without CA is virtually out of question. CA levels are also correlated with aging (Cabiscol and Levine, 1995). A variety of diseases have been associated with such oxidative damage, which includes Parkinson's disease, diabetes, rheumatoid arthritis and alzheimer's disease. Classes of CA have been briefly described in the next section.

\section{Types of CA and Mechanism of Action}

There are basically six types of CAs discovered till now, namely $\alpha$, $\beta, \gamma, \delta, \zeta$, and $\eta$. They don't have any specific sequence similarity, hence representing a classical case of convergent evolution (Lane and Morel, 2000; Smith and Ferry, 2000; Lapointe et al., 2008; Del Prete et al., 2014). Characteristic features of these classes are briefly described in Table 1.

Despite their structural differences, CAs have similar action mechanism. This mechanism has been widely studied in $\alpha$-CAs. It is a two-step ping-pong reaction that catalyzes the reversible hydration/dehydration of $\mathrm{CO}_{2}$ into bicarbonate and a proton (Silverman, 1982). A histidine residue present near the water molecule accepts a proton $\left(\mathrm{H}^{+}\right)$which gets released from the water molecule. It leaves only hydroxide ion attached to zinc ion. The active site has specific pockets for binding $\mathrm{CO}_{2}$, where it gets bound to the hydroxide ion. Further, nucleophilic attack on the carbonyl group by the zinc-bound hydroxide takes place that results in $\mathrm{HCO}_{3}^{-}$formation. The enzyme is then regenerated and the bicarbonate ion is released (Lindskog and Coleman, 1973; Silverman and Lindskog, 1988).

$$
\begin{aligned}
& \mathrm{EZnOH}^{-}+\mathrm{CO}_{2}+\mathrm{H}_{2} \mathrm{O} \longleftrightarrow \mathrm{EZnH}_{2} \mathrm{O}+\mathrm{HCO}_{3}^{-} \\
& \mathrm{EZnH}_{2} \mathrm{O}+\mathrm{PSR} \longleftrightarrow \mathrm{EZnOH}^{-}+\mathrm{PSR}-\mathrm{H}^{+} \\
& \mathrm{PSR}-\mathrm{H}^{+}+\mathrm{B} \longleftrightarrow \mathrm{PSR}+\mathrm{B}-\mathrm{H}^{+}
\end{aligned}
$$

\section{CA Specific Inhibitors and their Biological Relevance}

CA abnormality leads to several diseases such as edema, glaucoma, hypertension, epilepsy, and cancer (Supuran, 2008). Pharmaceuticals that suppress the activity of carbonic anhydrase are classified as carbonic anhydrase inhibitors. Their clinical use has been established as diuretics, anti-glaucoma agents and antiepileptics in the management of gastric and duodenal ulcers, mountain sickness, neurological disorders, or osteoporosis (Supuran et al., 2003). Among human CA isoforms, CAIX and CAXII have already been identified as potent drug targets and molecular markers for the treatment of various types of cancer and tumors. Both show upregulated expression in cancerous cells as compared to normal cells. The two isoforms are required for maintaining intracellular $\mathrm{pH}$ of tumor cells. The inhibition of these two CAs is, therefore, important for cancer treatment. Several workers and companies have developed several ureido and sulfonamide based pharmaceuticals for cancer treatment which inhibit CAIX and CAXII (Cabiscol and Levine, 1995; Lomelino and McKenna, 2016).

\section{Sulfonamide, Sulfamate, and Sulfamide Inhibitors}

Sulfonamides $\left(\mathrm{R}-\mathrm{NH}_{2} \mathrm{SO}_{2}\right)$ constitute an important group of classical drugs which have been known for their pharmaceutical and CA inhibitory properties. The most effective are the heterocyclic sulfonamides (acetazolamide, methazolamide, ethoxzolamide). Acetazolamide is one of the well-known inhibitors of carbonic anhydrase and has rendered its effectiveness for the in vivo inhibition of intracellular CAs (Teicher et al., 1992). It is used in the treatment of glaucoma, epilepsy (rarely), idiopathic intracranial hypertension, and altitude sickness. Similarly other sulfanamide inhibitors such

\begin{tabular}{|c|c|c|c|c|c|c|}
\hline Characteristics & $\alpha \mathbf{C A}$ & $\beta$ CA & $\gamma \mathbf{C A}$ & $\delta \mathbf{C A}$ & $\zeta \mathbf{C A}$ & $\eta \mathbf{C A}$ \\
\hline Occurrence & $\begin{array}{l}\text { Predominantly in animal } \\
\text { kingdom also found in } \\
\text { protozoa, algae, green } \\
\text { plants, and in some } \\
\text { archaea, bacteria and fungi }\end{array}$ & $\begin{array}{l}\text { Reported in all three } \\
\text { domains of life }\end{array}$ & $\begin{array}{l}\text { Eubacteria and Archaea } \\
\text { Methanosarcina } \\
\text { thermophila }\end{array}$ & $\begin{array}{l}\text { Thalassiosira } \\
\text { weissfogii }\end{array}$ & $\begin{array}{l}\text { Thalassiosira } \\
\text { weissfogii } \\
\text { (marine diatom) }\end{array}$ & $\begin{array}{l}\text { Plasmodium } \\
\text { falciparum }\end{array}$ \\
\hline Molecular weight & $\begin{array}{l}\text { monomeric (Mw: 26-37 } \\
\mathrm{kDa})\end{array}$ & $\begin{array}{l}\text { dimer, can form various } \\
\text { olgomeric structures } 45 \text { to } \\
200 \mathrm{kDa}\end{array}$ & homotrimer 60 kDa (native) & monomer27 kDa & $69 \mathrm{kDa}$ & - \\
\hline $\begin{array}{l}\text { Active site amino } \\
\text { acids }\end{array}$ & $\begin{array}{l}\text { His - 94, His - 96, His - } \\
119\end{array}$ & Cys 38, His 96 and Cys 99 & $\begin{array}{l}\text { His } 81 \text {, His } 122 \text { and His } \\
117\end{array}$ & - & - & $\begin{array}{l}\mathrm{His}-94, \mathrm{His}- \\
96, \mathrm{His}-118\end{array}$ \\
\hline Function & $\begin{array}{l}\mathrm{pH} \text { homeostasis, secretion } \\
\text { of } \mathrm{HCO}_{3}^{-} \text {, ion exchange }\end{array}$ & $\begin{array}{l}\text { cyanate degradation } \\
\text { (E.coli), } \mathrm{CO}_{2} \text { fixation } \\
\text { (cyanobacteria), }\end{array}$ & $\begin{array}{l}\text { acetate metabolism and } \\
\text { conversion of acetate to } \\
\text { methane (methanogens) }\end{array}$ & - & - & $\begin{array}{l}\text { Overexpressed } \\
\text { during } \\
\text { pathogenesis }\end{array}$ \\
\hline
\end{tabular}
as dorzolamide and brinzolamide are used in the treatment

TABLE 1 | Characteristic features of basic six classes of carbonic anhydrases.

Other features esterase activity, $\mathrm{N}-$ terminal signal peptide for periplasmic localisation or extracellular secretion
Overexpressed during pathogenesis of some pathogens (Salmonella) Basic component of Carbon Concentrating Mechanism (CCM) 
of glaucoma as well. Near about $20 \mathrm{CA}$ inhibitors have been granted FDA approval and they are being put to wide clinical usage (More et al., 1946; Sugrue, 2000; Frost and McKenna, 2013; Wulf and Matuszewski, 2013; Supuran, 2016a). Sulfamic acid $\left(\mathrm{NH}_{3} \mathrm{SO}_{3}\right)$ and sulfamide $\left(\mathrm{NH}_{2} \mathrm{SO}_{2} \mathrm{NH}_{2}\right)$ are the simplest $\mathrm{CA}$ inhibitors containing the $-\mathrm{NH}_{2} \mathrm{SO}_{2}$ moiety. However, the sulfonamides are less effective against some of the $\beta$-CAs like Cab and also some of the $\gamma$-CAs (Zimmerman et al., 2004) and fungal MG-CA where they inhibit in millimolar/micromolar concentrations. Sulfamic acid and sulfamide are the weakest with inhibition constants $\left(K_{i}\right)$ in the millimolar range. Interestingly, a completely different inhibition profile was observed against Zn-Cam and MG-CA, where sulfamic acid and sulfananilamide were shown to be more potent than sulfonamide inhibitors. Over the years various other inhibitors of CAs (benzenesulfonamides, arylbenzenesulfonamides, tetrafluorobenzenesulfonamides, 4-aminoethylbenzenesulfonamide) have been synthesized/discovered and their potential inhibitory properties have been evaluated (Pastoreková and Pastorek, 2004; Pala et al., 2014). Two CAs (LpCA1 and LpCA2) from Legionella pneumophila, a pathogenic bacterium, also get inhibited by sulfanamide inhibitors (sulfonylated aromatic sulphonamides, acetazolamide, ethoxzolamide, methazolamide, and dichlorophenamide). They can serve as a promising drug target for this pathogen (Supuran, 2016b). MGM Institute of Health Sciences has developed cerium oxide nanoparticles which are plant based that exhibit CA inhibitory and antioxidant properties (Lomelino and McKenna, 2016). An electrochemical enzyme inhibition biosensor, based on CA entrapped in a carbon paste electrode using carbon black nanoparticles and solid paraffin, was developed that measures sulfanilamide inhibition of CA (Bourais et al., 2017). This biosensor can even detect the sub-micromolar levels of sulfanilamide and the detection limit was $0.4 \mu \mathrm{m}$ (Bourais et al., 2017).

\section{Novel Inhibitors}

Coumarins, phenols, polyamines, fullerenes, boronic acid and their substituted derivatives have been effective against animal CAs (Innocenti et al., 2009b; Carta et al., 2012; Supuran, 2013). Their efficacy against microbial CAs, however, must be investigated. Carta et al. (2012) recently introduced dithiocarbamates (DTCs) as a new class of Zn-binding CA inhibitors, which can interact with the nearby amino acid residues for effective binding. Indeed these promising inhibitors have been effective even in sub-nanomolar concentrations. Nitroimidazoles decrease the $\mathrm{pH}$ of the hypoxic cancer cells, thereby helping in the uptake of chemotherapeutic agents. Scientists are also developing CA inhibitory antibodies for cancer treatment (Lomelino and McKenna, 2016). Incorporation of sugar moieties into sulfanilamide has resulted in sharp improvement in their solubility and effectiveness. The inhibition constants for ribose and galactose sulfanilamides against bsCA1 were reduced to 8.9 and $9.2 \mathrm{nM}$ as compared to $2,500 \mathrm{nM}$ for the unsubstituted sulfanilamide. In contrast to other sulfonamides and sulfanilamides, glycosylsulfanilamides have a good balance between its hydro- and liposolubility, therefore, it can easily penetrate through membranes to affect the growth of microorganisms (Supuran, 2015). Mete et al. (2016) synthesized a series of new thienyl-substituted pyrazoline benzenesulfonamides and showed their effective inhibition against hCAI and hCAII.

\section{Thermo-Alkalistable Carbonic Anhydrases}

Advances in recombinant DNA technology have enabled us to modify/change a protein's structure and function as per the demand. As already stated, utilization of CAs in biomineralization of $\mathrm{CO}_{2}$ requires the enzyme to be alkalistable as the mineralization is favored at alkaline $\mathrm{pH}$ (Farrell, 2011) and the temperature of flue gas is too high (around $140^{\circ} \mathrm{C}$ ), which is cooled to about $60^{\circ} \mathrm{C}$ for post-combustion $\mathrm{CO}_{2}$ capture. Hence, the enzymes needed for carbon sequestration must be thermostable. Several efforts have been made to modify the mesophilic CAs in order to make them thermo-alkali-stable. $\mathrm{CO}_{2}$ Solutions Inc. has developed a thermally optimized CA by genetic engineering which is stable at $90^{\circ} \mathrm{C}$ for $24 \mathrm{~h}\left(\mathrm{CO}_{2}\right.$ Solutions Inc., 2012). Fisher et al. (2012) modified the surface amino acid residues of hCAII (which are far away from active site) to increase the thermostability by $6^{\circ} \mathrm{C}$. Some of the amino acid residues present at the surface (Tyr7, Leu224, Leu100, Leu240, Asn67, and Asn62) were replaced by Phe, Ser, His, Pro, Gln, and Leu, respectively. Directed evolution technique was utilized in order to develop a thermostable CA from $\beta$-CA from Desulfovibrio vulgaris. It can even retain activity at $107^{\circ} \mathrm{C}$. The enzyme was stable in the presence of primary flue gas contaminats such as NOx and SOx as well as in the presence of $4.2 \mathrm{M}$ concentration of $\mathrm{N}$-methyl-diethanolamine (MDEA) at $50^{\circ} \mathrm{C}$ for about 14 weeks. The enzyme retains $40 \%$ residual activity at alkaline $\mathrm{pH}$ (11.8). This highly stable CA has been efficiently used for biomineralization of $\mathrm{CO}_{2}$ at high temperature $\left(87^{\circ} \mathrm{C}\right.$ ) (Alvizo et al., 2014). A whole cell bacterial catalyst was generated from the CA of Neisseria gonorrhoeae ( $n g \mathrm{CA}$ ) by engineering it in such a way that it is secreted in the periplasm of $E$. coli. This whole cell catalyst was also found stable at low $\mathrm{pH}$. It might be possible to sequester $\mathrm{CO}_{2}$ more efficiently using whole cell enzyme systems even at a $\mathrm{pH}$ below the $\mathrm{pKa}$ of $\mathrm{HCO}^{3-}$ or $\mathrm{CO}_{3}^{2-}$, thereby reducing the cost of maintaining it at elevated $\mathrm{pH}$ (Jo et al., 2013). The modified CA thus generated by these strategies can aid in efficiently capturing $\mathrm{CO}_{2}$, but adds to the cost. It is worthwhile to search for enzymes that are stable at two/more extreme conditions. The use of thermo-alkali-stable CA from polyextrmophiles would simplify the process. Jo et al. (2016) engineered the de-novo sulfide bond of ngCA which resulted in enhancement in both kinetic and thermodynamic stabilities. The major reason for this enhancement is the loss of conformational entropy of the unfolded state, thereby increasing rigidity.

Recent advances in technology have enabled biologists to reach the extreme maxima of earth, sea and sky for exploring their diversity. Extremophiles have been isolated from a wide array of extreme environments like deep sea vents, hot springs, upper troposphere and stratosphere, outer space and others (Wilson and Brimble, 2009). There are also reports on the isolation of polyextremophiles from mines and industries (Onstott et al., 2003; Bhojiya and Joshi, 2012). Their characterization and applications have added new dimension 
to applied biology. Polyextremophiles are known to produce a variety of useful products (Coker, 2016). Metagenomics and data mining studies have revealed the presence of $\alpha$, $\beta, \gamma$ CA genes in microbes from stressed environments. $\beta-$ CA from Methanobacterium thermoautotrophicum (CabCA) and $\gamma$-CA from Methanosarcina thermophila (CamCA) were the first known CAs from extremophiles (Alber and Ferry, 1994; Smith and Ferry, 2000). Two novel and highly thermo-alkalistable $\alpha$-CAs (SazCA and Ssp CA) have been discovered from thermophilic archaea Sulfurihydrogenibium azorense and Sulfurihydrogenibium yellowstonense. YO3AOP1, respectively. The former being one of the fastest known CAs till date $\left(\mathrm{k}_{\mathrm{cat}} /\right.$ $\mathrm{K}_{\mathrm{m}}$ value of $3.5 \times 10^{8} \mathrm{M}^{-1} \mathrm{~s}^{-1}$ ) (De Luca et al., 2013). SSp $\mathrm{CA}$ is even active after $3 \mathrm{~h}$ incubation at $70^{\circ} \mathrm{C}$. SazCA is also highly thermostable having 53 days and 8 days of halflife at $40^{\circ}$ and $70^{\circ} \mathrm{C}$, respectively. It retains carbon dioxide hydration activity even after incubation at 80 and $90^{\circ} \mathrm{C}$ for several hours (Russo et al., 2013). Both these enzymes are alkalistable (active at $\mathrm{pH}$ 9.6) and stable in the presence of flue gas contaminants such as $\mathrm{NO}^{2-}, \mathrm{NO}^{3-}$, and $\mathrm{SO}_{4}^{2-}$ (Vullo et al., 2012; De Luca et al., 2013). Two highly thermophilic bacteria isolated from hydrothermal vent ecosystems Persephonella marina EXH1 (PMCA) and Thermovibrio ammonificans produced highly thermostable $\alpha$-CA. The CA of T. ammonificans (TaCA) was more stable than SazCA and SspCA. This enzyme (taCA) showed thermo-stimulating properties (activity of taCA was elevated after the high temperature incubation (Jo et al., 2014). Faridi and Satyanarayana (2016a) reported a moderately thermostable and highly alkalistable $\alpha-\mathrm{CA}(\mathrm{BhCA})$ from polyextremophilic bacterium Bacillus halodurans. It has a unique property of sulfate stimulation (its activity enhanced in the presence of sulfate ions). This property can be exploited for CCS as the flue gas contains SOx as one of the contaminants. BhCA did not get denatured in the presence of EDTA (Faridi and Satyanarayana, 2016b). Bose and Satyanarayana (2016) reported a moderately thermostable and alkalistable $\gamma$-CA from Aeribacillus pallidus, a polyextremophilic bacterium. Both ApCA and BhCA were stable in presence presence of bicarbonate (0.1M). Psychrobacter sp. SHUES1 isolated from frozen alkaline samples from Shanghai (China) produced carbonic anhydrase and urease which are important in microbially induced carbonate precipitation (MICP; Li et al., 2016). List of some of the thermoalkali-stable CAs which have been characterized in the last few years have been highlighted in Table 2 with their characteristics.

Crystal structures of three of the most thermo-alkali-stable CAs were solved and their analysis revealed the reasons of their higher thermostabilities. As per the crystallographic structure, SspCA was found to have increased structural compactness. It contained a large number of charged residues on the protein surface with a greater number of ionic networks. These might be the key factors involved in the higher thermostability of this enzyme with respect to its mesophilic homologs. It has a fold which is characterized by a 10-stranded centrally placed $\beta$-sheet, which is surrounded by several helices and $\beta$ strands. A deep conical cavity that extends from the center to the protein surface harbors the active site. Several polar and hydrophobic interactions play active role in stabilization of SspCA. SazCA has a similar structure to that of SSpCA with minor differences. SspCA has Glu2 and Gln207 residues which are substituted with His2 and His207 in SazCA. This substitution is responsible for higher SazCA catalytic activity. The crystallographic structures of both SazCA and SspCA confirmed the dimeric nature of the enzymes (Di Fiore et al., 2013; De Simone et al., 2015). Crystallographic structure analysis of TaCA revealed it to be similar to the structure of other previously known bacterial homologs (Huang et al., 1998; Di Fiore et al., 2013; De Simone et al., 2015), but having entirely novel oligomeric pattern. Indeed TaCA forms a tetramer that comprises two dimers, which are structurally similar to that of SazCA and SspCA. The two dimers are joined together by two intermolecular disulfide bridges and by inter-subunit ionic interactions (James et al., 2014). This tetrameric state may be a possible reason for the enhanced thermostability of TaCA. Tahirov et al. (1998) recorded that thermostable enzymes have higher degree of oligomerization than mesophilic enzymes. It is also worthwhile to mention that the two conserved cysteine residues, Cys202 and Cys47, are reduced partially in SspCA and SazCA due to insufficiently oxidative expression conditions. It is suggested that the presence of two cysteine residues in TaCA leads to its increased stability (James et al., 2014). These structural analyses of thermostable CAs not only provide structural insights of the enzymes but also aid in their modification, so that they can be efficiently utilized for biomineralization.

\section{Utilization of Thermo-alkali-stable CAs in Biomineralization}

Several strategies are being developed for utilization of thermo-alkali-stable CAs in mitigating global warming. $\mathrm{CO}_{2}$ Solutions Company has developed a CA based reactor for capturing $\mathrm{CO}_{2}$ from different $\mathrm{CO}_{2}$ intensive industries (http:// www.co_2solutions.com/en/the-process). This process requires immobilized CA. Utilization of thermo-alkali-stable CAs for carbon capture requires a series of bioreactors which will have direct supply of flue gas. It is directly supplied to a bioreactor containing the immobilized enzyme. This enzyme in aqueous condition will hydrate $\mathrm{CO}_{2}$ present in flue gas and releases $\mathrm{HCO}_{3}^{-}$and $\mathrm{H}^{+}$. Alvizo et al. (2014) developed a process which utilizes a highly thermostable $\beta$-CA engineered from the $\beta$-CA of Desulfovibrio vulgaris. In this process, the set up consists of absorber column where carbon dioxide gets absorbed into MDEA; CA present in the column generates proton and bicarbonate. The residual flue gas is released and the rest (bicarbonate+amine $+\mathrm{CA}$ ) is transferred to the next column maintained at $87^{\circ} \mathrm{C}$, where $\mathrm{CO}_{2}$ is again regenerated, accompanied by regeneration of the solvent. Pure $\mathrm{CO}_{2}$ is later reutilized and the solvent returns back to the initial absorber column for the next cycle. The rate of $\mathrm{CO}_{2}$ absorption increases by about 25 -fold in the catalyzed reaction as compared to the non-catalyzed reaction. Normal conditions for steadystate experiments were $2 \mathrm{l}$ per minute of solvent, $180 \mathrm{l}$ per minute of flue gas at $25^{\circ} \mathrm{C}$ and absorber and desorber temperature at $87^{\circ} \mathrm{C}$. All enzyme-solvent mixtures were made 
TABLE 2 | Thermostable CAs and their characteristic features.

\begin{tabular}{|c|c|c|c|c|c|}
\hline SI. No. & Enzyme & Organism & Class & Characteristic features & References \\
\hline 1. & SspCA & $\begin{array}{l}\text { Sulfurihydrogenibium } \\
\text { yellowstonense. YO3AOP1 }\end{array}$ & $\alpha$ & $\begin{array}{l}\text { Dimer, Stable at high } \\
\text { temperatures }\left(70^{\circ} \mathrm{C} \text { for } 3 \mathrm{~h}\right) \\
\text { Optimum working } \\
\text { condition- } 95^{\circ} \mathrm{C}, \mathrm{pH} 9.6\end{array}$ & Capasso et al., 2012 \\
\hline 2. & Saz CA & Sulfurihydrogenibium azorense & $\alpha$ & $\begin{array}{l}\text { Dimer, Half-life at } 70^{\circ} \mathrm{C} \text { is } 8 \\
\text { days and } 53 \text { days at } 50^{\circ} \mathrm{C} \text {. } \\
\text { Alkalistable }(\mathrm{pH} 9.6)\end{array}$ & $\begin{array}{l}\text { De Luca et al., 2013; Russo } \\
\text { et al., } 2013\end{array}$ \\
\hline 4. & PmCA & Persephonella marina EX-H1 & $\alpha$ & $\begin{array}{l}88 \text { days of half-life at } 100^{\circ} \mathrm{C} \text {, } \\
\text { Dimer }\end{array}$ & $\begin{array}{l}\text { Jo et al., 2014; Kanth et al., } \\
2014\end{array}$ \\
\hline 5. & Cab CA & $\begin{array}{l}\text { Methanobacterium } \\
\text { thermoautotrophicum }\end{array}$ & $\beta$ & $\begin{array}{l}\text { Tetramer Optimal } \mathrm{CO}_{2} \\
\text { hydration activity at } 75^{\circ} \mathrm{C}\end{array}$ & Smith and Ferry, 2000 \\
\hline 7. & $\begin{array}{l}\text { MtCam (anaerobicaly } \\
\text { purified) }\end{array}$ & Methanosarcina thermophila & $\gamma$ & NA & Tripp et al., 2004 \\
\hline 8. & $\begin{array}{l}\text { MtCam (expressed in } M \text {. } \\
\text { acetivorans) }\end{array}$ & Methanosarcina thermophila & $\gamma$ & $\begin{array}{l}\mathrm{Fe}^{2+} \text { present at active site } \\
\text { enhances its activity }\end{array}$ & MacAuley et al., 2009 \\
\hline 9. & BhCA & Bacillus halodurans & $\alpha$ & $\begin{array}{l}\text { Thermo-alkali-table (pH 6-11), } \\
\text { gets stimulated in the presence } \\
\text { of SOx, stable with EDTA }\end{array}$ & $\begin{array}{l}\text { Faridi and Satyanarayana, } \\
2016 a\end{array}$ \\
\hline 10. & ApCA & Aeribacillus pallidus & $\gamma$ & $\begin{array}{l}\text { Thermo-alkali-stable }(\mathrm{pH} 8-11) \text {, } \\
\text { stable in the presence of SOx } \\
\text { and } \mathrm{NOx}\end{array}$ & $\begin{array}{l}\text { Bose and Satyanarayana, } \\
2016\end{array}$ \\
\hline
\end{tabular}

using normal tap water without any further treatment (Alvizo et al., 2014). CAs from Caminibacter mediatlanticus (CmCA) and Sulfurihydrogenibium yellowstonense YO3AOP1 (SspCA), both belonging to $\alpha$-class, have been used to capture $\mathrm{CO}_{2}$ from flue gas (Daigle and Fradette, 2014; Rossi, 2014). SspCA was characterized as prospective biocatalyst for $\mathrm{CO}_{2}$ capture as it has regenerative absorption ability in alkaline conditions. Its prolonged half life (53 days at $40^{\circ} \mathrm{C}$ and 8 days at $70^{\circ} \mathrm{C}$ ) making it one of the most suitable candidates for CCS. Ssp CA was, therefore, tested for its biomimetic carbon sequestration (Russo et al., 2013). Ssp CA immobilized in polyurethane foam (PU-SspCA) has been used in designing a bioreactor to mimic $\mathrm{CO}_{2}$ capture process in industries (Migliardini et al., 2014). The immobilized CA (PU-SspCA) showed exceptional thermostability for very long duration even at $70^{\circ} \mathrm{C}$ and was highly stable at $100^{\circ} \mathrm{C}$ even after $48 \mathrm{~h}$ (Capasso et al., 2012). Heat stable carbonic anhydrases from $M$. thermophila and Caminibacter sp. have been used in bioreactors for efficient $\mathrm{CO}_{2}$ removal from flue gases. Pyrococcus horikoshii and $M$. thermophila secreted $\gamma$-CA which was used in developing $\gamma-$ CA nanoassemblies. These assemblies were developed by joining the single entitites to make multiple linked interactions with the surface of the reactor. Biotinylation sites were created by specifically mutating some of the residues to cysteines. Firm nanostructures were thus created by cross-linking biotinylated$\gamma$-CAs with streptavidin tetramers (Salemme and Weber, 2014).
There are basically three different crystal phases for calcium carbonate $\left(\mathrm{CaCO}_{3}\right)$, viz. calcite (rhombic), aragonite (needle like) and vaterite (spherical)]. Calcite phase is thermodynamically the most stable phase, while the vaterite is the metastable phase which is more soluble (Favre et al., 2009). When PMCA and TaCA (both $\alpha$-CAs) were utilized for biomineralization; it resulted in the formation of stable calcite (Jo et al., 2014). $\alpha$-CA from Dunaliella sp. produced $8.9 \mathrm{mg}$ of calcite per $100 \mu \mathrm{g}(172 \mathrm{U} / \mathrm{mg})$ of enzyme in presence of $10 \mathrm{mM}$ $\mathrm{Ca}^{2+}$ (Kanth et al., 2012). Another thermo-alkali-stable $\gamma$ CA (ApCA) from polyextremophilic bacterium A. pallidus was used for biomineralization and well faceted rhombohedral calcite crystals were observed when viewed under scanning electron microscopy (SEM; Figure 1). The partially purified enzyme caused precipitation of $42.5 \mathrm{mg} \mathrm{CO} \mathrm{CO}_{3}^{2-} \mathrm{mg}^{-1}$ protein (Bose and Satyanarayana, 2016). Optimization of the process parameters led to an increase in carbonate precipitation up to $200 \mathrm{mg} \mathrm{CO}_{3}^{2-} \mathrm{mg}^{-1}$ protein (Bose and Satyanarayana, 2017).

When a highly alkalistable and moderately thermostable a-CA (BhCA) from Bacillus halodurans was used for biomineralization, well defined calcite crystals were observed (Faridi and Satyanarayana, 2016a). ApCA and BhCA were also utilized for testing their efficacy in $\mathrm{CO}_{2}$ sequestration from flue gas using vehicular exhaust (Figure 2). Vehicular exhaust has a comparable composition as that of flue gas emitted from the thermal power plants $\left(\sim 71 \% \mathrm{~N}_{2}, 14 \% \mathrm{CO}_{2}, 1-2 \%\right.$ 


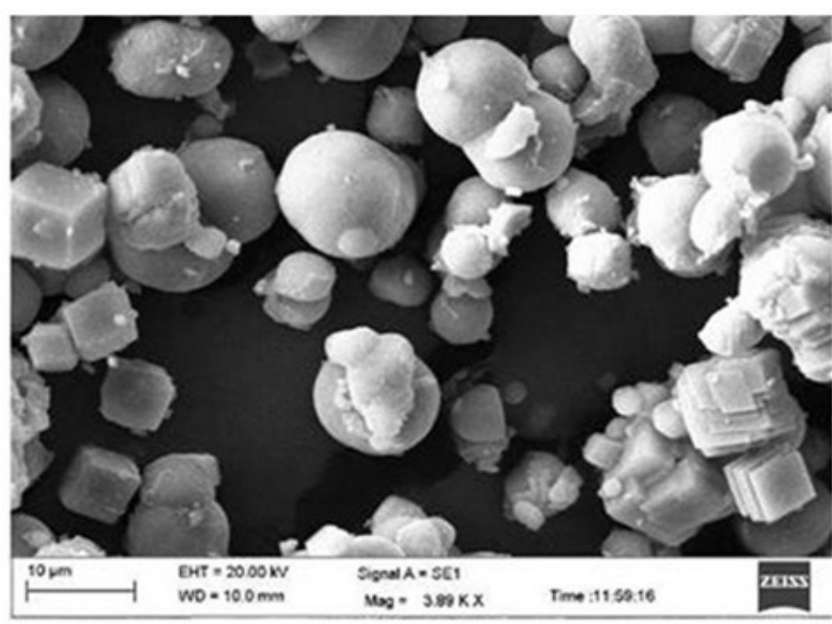

A

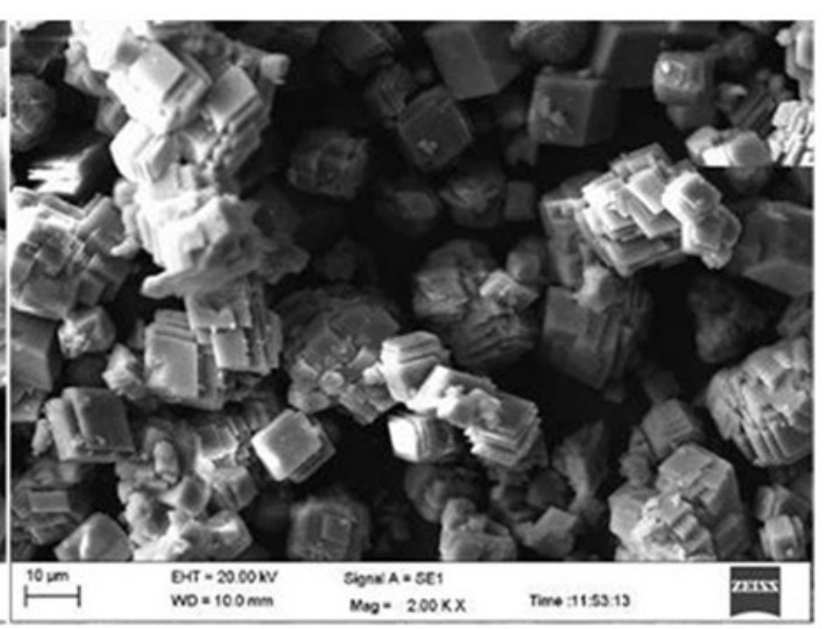

B

FIGURE 1 | Scanning electron microscopic picture of calcium carbonate crystals in the presence and absence of CA (control). (A) Spherical vaterite crystals were formed in the control. (B) Rhombohedral and well faceted calcite crystals were formed in the presence of ApCA (adopted from Bose and Satyanarayana, 2016).

hydrocarbons, carbon monoxide, $\mathrm{NO}_{\mathrm{x}}$, and minor amount of $\mathrm{SO}_{2}$; Perry and Gee, 1995). Both the enzymes were useful in sequestering $\mathrm{CO}_{2}$ from vehicular exhaust, hence making them efficient candidates for biomineralization (Faridi and Satyanarayana, 2016b; Figure 3). Biomineralization process for ApCA and BhCA was performed at $37^{\circ} \mathrm{C}$ in a $75 \mathrm{~mL}$ total reaction volume. CA (0.05 mg) was dispersed in $15 \mathrm{~mL}$ Tris buffer containing $0.9 \mathrm{~g}$ of $\mathrm{CaCl}_{2} \cdot 2 \mathrm{H}_{2} \mathrm{O}$ in Tris (2.52 g) buffer according to a protocol used by Mirjafari et al. (2007). To initiate the mineralization process, $60 \mathrm{~mL}$ of $\mathrm{CO}_{2}$ solution was added to the enzyme mix. The reaction was performed for $10 \mathrm{~min}$ at $37^{\circ} \mathrm{C}$. In an interesting study, the effect of CA from Bacillus mucilaginosus on carbonate formation and wollastonite dissolution were explored under variable $\mathrm{CO}_{2}$ conditions. Real time PCR was used to analyze the correlation between CA gene expression, sufficiency or deficiency of calcium and $\mathrm{CO}_{2}$ concentration. The findings reaffirmed the belief that $\mathrm{CO}_{2}$ concentration is not related to effects of CA. Further, they also showed that microbial CA has some role in silicate weathering (Xiao et al., 2014). Some of the other alkalistable CAs have also shown efficacy in carbon sequestration. Another $\alpha-C A$ from Serratia sp., which was alkalistable in nature, was successful in generating calcite crystals (Srivastava et al., 2015). Some of the mesophilic CAs from some other microorganisms such as Pseudomonas fragi $(27.33 \mathrm{mg}$ $\mathrm{CO}_{3}^{2-} / \mathrm{mg}$ of protein), Bacillus pumillus (25.43 $\mathrm{CO}_{3}^{2-} / \mathrm{mg}$ of protein), M. lylae (24.02 $\mathrm{CO}_{3}^{2-} / \mathrm{HCO}^{3-} / \mathrm{mg}$ of protein) (Prabhu et al., 2011) and Citrobacter freundii SW3 (Ramanan et al., 2009) [ $225 \mathrm{mg} \mathrm{CO} 3^{2-} / \mathrm{mg}$ of protein] also produced calcite crystals. Rhodobacter sphaeroides was genetically modified to harbor a surface displayed CA with inducible expression of phosphoenolpyruvate carboxylase led to very high $\mathrm{CO}_{2}$ reduction efficiency and the production of several organic compounds (carotenoids, polyhydroxybutyrate, malic acid, succinic acid; Park et al., 2017).

\section{Production and Over Expression of Carbonic Anhydrase Genes by Molecular Approaches}

One of the key factors that determine the cost effectiveness of any biotechnological application is the availability and cost of the biocatalysts. Microorganisms are well known to produce CAs for use in CCS technologies. Researchers have also displayed the ability of many prokaryotic species such as planktonic Bacillus mojavensis cells for microbially enhanced CCS by mineral trapping and solubility trapping (Mitchell et al., 2010). The production levels of CAs are, however, quite low for industrial use. Hence the production parameters must be optimized. Statistical approaches such as Response surface methodology (RSM) and two factorial designs are some of the well-known methods for optimizing production of biocatalysts (Kumar and Satyanarayana, 2014). The production of carbonic anhydrase is growth associated; hence, optimization of growth parameters leads to high enzyme titres. Optimization of growth conditions by mono-factor tests with blank control and orthogonal design methodology resulted in 7 -fold increase in CA titres in $B$. mucilaginosus K02 (Zhang et al., 2011). Bose and Satyanarayana (2016) reported about 4 -fold increment in enzyme titres on optimization of growth parameters. In both the studies, the CA production was found to be synchronous to that of the growth of the bacterium. The CA production by the wild type strain becomes too cumbersome. The production of CA from thermoalkaliphilic microorganisms is difficult as it is not easy to provide accurate conditions [anaerobic, high temperature, $\mathrm{pH}$ (high/low) etc.] for their growth and enzyme production. Many archaeal life forms producing bioactive compounds need specialized growth conditions (Alber and Ferry, 1994; Mesbah and Wiegel, 2012). The advent of genome mining, metagenomics and bioinformatics approaches have enabled to use molecular biological tools for cloning and over expression of industrially relevant enzymes in prokaryotic (E. coli, Bacillus subtilis) and eukaryotic (Pichia 


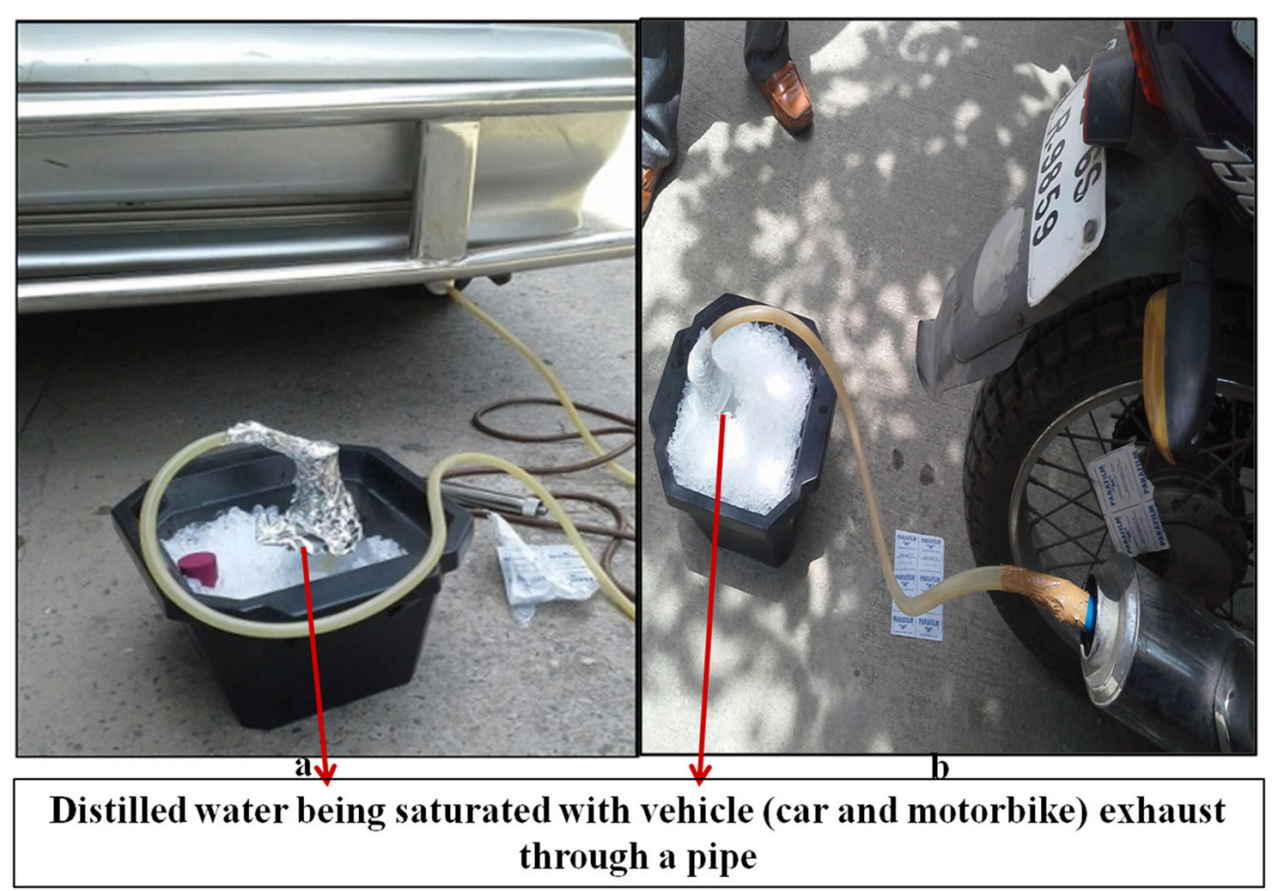

FIGURE 2 | Exhaust fumes from the petrol driven car and motorcycle were collected by connecting one end of a plastic pipe to the exhaust of the car and the other to saturate distilled water (DW) kept in ice bath for an hour which served as a source of $\mathrm{CO}_{2}$ (adopted from Faridi and Satyanarayana, $2016 \mathrm{a}$ ).

pastoris) hosts. Downstream processing becomes easy as the enzymes have various protein tags (e.g., His, GST) for easy purification of the recombinant proteins (Swartz, 2001). Since late 1990s, the prokaryotic CA genes from different strata have been cloned and the protein was over expressed in E. coli for analytical and application purposes. The first CA gene cloned from prokaryotes was $\alpha-\mathrm{CA}$ (NCA) from $N$. gonorrhoeae, which encoded a protein of $28 \mathrm{kDa}$ (Chirică et al., 1997). This enzyme was also expressed heterologously in $E$. coli as a periplasmic protein in order to use it as a whole cell biocatalyst (Jo et al., 2013). The yield of $\sim 106 \mathrm{mg} \mathrm{L}^{-1}$ with a specific activity of 3090 $\mathrm{U} \mathrm{mg}^{-1}$ in the pure protein was achieved (Kim et al., 2012).

Since then many other microbial CAs have been cloned and expressed in prokaryotic hosts. Many researchers have already cloned and over expressed all the CA-encoding genes from E. coli (can, cynT, cynT2, caiE, pay, and $y r d A$ ) and studied their expression profiles in response to different growth conditions (Fujita et al., 1994; Cronk et al., 2001; Merlin et al., 2003). CA genes from thermophilic bacteria such as Thermovibrio ammonificans, M. thermobacterium, $M$. thermophila, Sulfurihydrogenibium, B. halodurans and others have been cloned and over expressed in E. coli to assess their efficacy in biomineralization. These CAs have been shown to be useful in sequestering $\mathrm{CO}_{2}$ from flue gas (Capasso et al., 2012; Faridi and Satyanarayana, 2016a). The role of CAs in virulence/pathogenesis have been studied. They play an active role in metabolism during pathogenesis in many bacterial and fungal pathogens such as Vibrio cholerae, Helicobacter pylori, Candida albicans, Aspergillus fumigatus, and others. List of CAs from some of the pathogens have been summarized in Table 3.

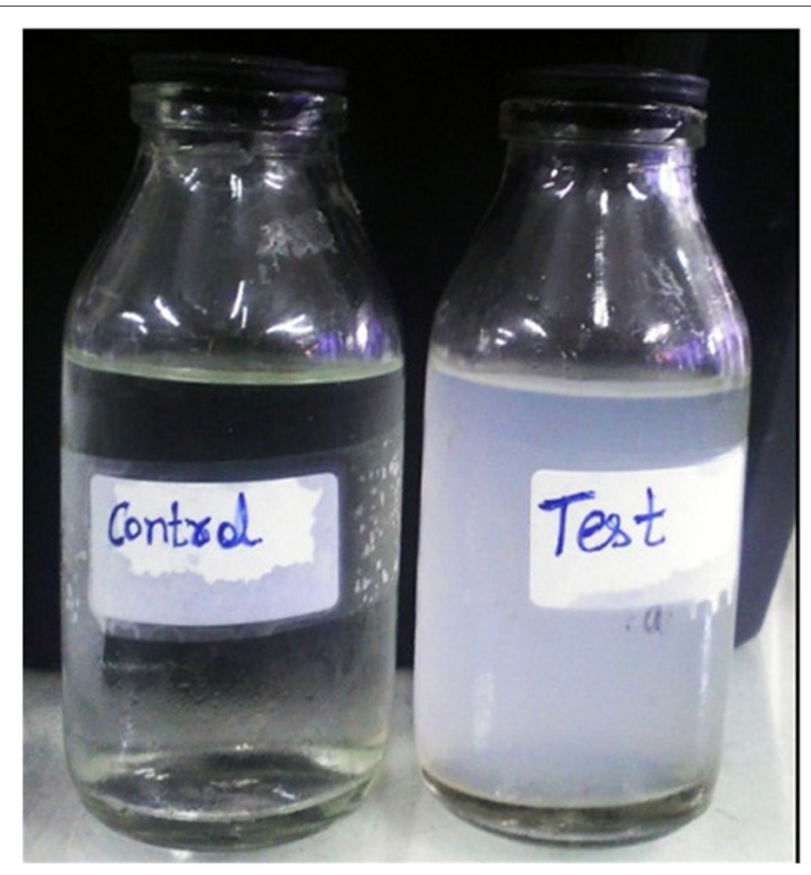

FIGURE 3 | Mineralization of vehicular exhaust gas $\mathrm{CO}_{2}$ using BhCA in the presence of $\mathrm{Ca}^{2+}$. Test reaction containing $\mathrm{CA}$ showed efficient mineralization of $\mathrm{CO}_{2}$ as compared to the control (adopted from Faridi and Satyanarayana, 2016a).

One of the major problems with cloning of genes in heterologous hosts is obtaining the active protein in soluble 
TABLE 3 | Characteristics of CA from some pathogenic bacteria.

\begin{tabular}{|c|c|c|c|c|c|c|}
\hline SI. No. & Organism & Type & Cloning Vector/Host & Molecular weight & Other Features & References \\
\hline 1 & V. cholerae & $\alpha$ & E. coli (pET15b) & $26.4 \mathrm{kDa}$ & $\begin{array}{l}\mathrm{K}_{\mathrm{m}}=11.7 \mathrm{mM} \mathrm{k} \mathrm{k}_{\text {cat }}=8.23 \\
\times 10^{5} \mathrm{~s}^{-1} \mathrm{k}_{\mathrm{cat}} / \mathrm{K}_{\mathrm{M}}=7.0 \\
\times 10^{7} \mathrm{M}^{-1} \mathrm{~s}^{-1}\end{array}$ & Del Prete et al., 2012 \\
\hline 2 & Brucella suis & $\mathrm{B}$ & E. coli (pET15b) & $25 \mathrm{kDa}$ & $\begin{array}{l}\mathrm{k}_{\text {cat }}=1.1 \times 10^{6}, \mathrm{k}_{\text {cat }} / \mathrm{K}_{\mathrm{m}} \\
=8.9 \times 10^{7} \mathrm{M}^{-1} \mathrm{~s}^{-1}\end{array}$ & Joseph et al., 2010 \\
\hline 3 & H. pylori & $\alpha$ & E. coli (pACA1) & $28.28 \mathrm{kDA}$ & $\begin{array}{l}\mathrm{k}_{\text {cat }}=2.4 \times 10^{5} \mathrm{~s}^{-1} \\
\mathrm{~K}_{\mathrm{M}}=17 \mathrm{mM} \mathrm{kcat} / \mathrm{K}_{\mathrm{M}}= \\
1.4 \times 10^{7} \mathrm{M}^{-1} \mathrm{~s}^{-1} \text { at } \mathrm{pH} \\
8.9 \text { and } 25^{\circ} \mathrm{C}\end{array}$ & Chirica et al., 2001 \\
\hline 4 & $\begin{array}{l}\text { Salmonella } \\
\text { typhimurium }\end{array}$ & $\begin{array}{l}\beta \text { (two stCA1 and } \\
\text { stCA2) }\end{array}$ & E. coli (pGEX-4T2) & $\begin{array}{l}24.8 \mathrm{kDa}(\mathrm{stCA} 1) 26.6 \\
\mathrm{kDa}(\mathrm{stCA} 2)\end{array}$ & $\begin{array}{l}\mathrm{k}_{\text {cat }}=0.79 \times 10^{6} \mathrm{~s}^{-1} \text { and } \\
1.0 \times 10^{6} \mathrm{~s}^{-1}, \mathrm{k}_{\mathrm{cat}} / \mathrm{K}_{\mathrm{m}} \\
=5.2 \times 10^{7} \mathrm{M}^{-1} \mathrm{~s}^{-1} \text { and } 8.3 \\
\times 10^{7} \mathrm{M}^{-1} \mathrm{~s}^{-1}\end{array}$ & Vullo et al., 2011 \\
\hline 5 & $\begin{array}{l}\text { Mycobacterium } \\
\text { tuberculosis }\end{array}$ & $\beta(\mathrm{mtCA} 1)$ & E. coli pGEX-4T2 & NA & $\begin{array}{l}\mathrm{k}_{\mathrm{cat}}=3.9 \times 10^{5} \mathrm{~s}^{-1} \mathrm{k}_{\text {cat }} / \\
\mathrm{K}_{\mathrm{m}}=3.7 \times 10^{7} \mathrm{M}^{-1} \mathrm{~s}^{-1}\end{array}$ & Minakuchi et al., 2009 \\
\hline 7 & $\begin{array}{l}\text { Plasmodium } \\
\text { falciparum }\end{array}$ & $\eta(\mathrm{PfCA})$ & E. coli & NA & $\begin{array}{l}\mathrm{k}_{\text {cat }}=1.4 \times 10^{5} \\
\mathrm{~s}^{-1} \mathrm{k}_{\text {cat }} / \mathrm{K}_{\mathrm{m}}=5.4 \times 10^{6} \\
\mathrm{M}^{-1} \mathrm{~s}^{-1}\end{array}$ & Del Prete et al., 2014 \\
\hline 8 & $\begin{array}{l}\text { Haemophilus } \\
\text { influenzae }\end{array}$ & $\beta(\mathrm{HICA})$ & E. coli & $\begin{array}{l}105.26 \text { kDA (native } \\
\text { molecular weight) }\end{array}$ & $\begin{array}{l}\text { Tetramer, presence of a } \\
\text { novel non-catalytic } \\
\text { bicarbonate binding site, } \\
\mathrm{k}_{\text {cat }}, \mathrm{k}_{\text {cat }} / \mathrm{K}_{\mathrm{m}} \text { is } \mathrm{pH} \\
\text { dependent }\end{array}$ & Cronk et al., 2006 \\
\hline 9 & $\begin{array}{l}\text { Candida } \\
\text { albicans }\end{array}$ & $\beta$ (Nce103) & & $31.5 \mathrm{Da}$ & $\begin{array}{l}\mathrm{k}_{\mathrm{cat}}=8.0 \times 10^{5} \\
\mathrm{~s}^{-1} \mathrm{k}_{\text {cat }} / \mathrm{K}_{\mathrm{m}}=9.7 \times 10^{7} \\
\mathrm{M}^{-1} \mathrm{~s}^{-1}\end{array}$ & Innocenti et al., 2009a \\
\hline 12 & $\begin{array}{l}\text { Aspergillus } \\
\text { fumigatus }\end{array}$ & $\begin{array}{l}\text { 4- } \beta C A s \\
\text { (cafA-cafD) }\end{array}$ & Saccharomyces cerevisiae & - & $\begin{array}{l}\text { All four CAs strongly } \\
\text { expressed during } \\
\text { pathogensis }\end{array}$ & $\begin{array}{l}\text { Han et al., 2010; Tobal } \\
\text { and Balieiro, } 2014\end{array}$ \\
\hline
\end{tabular}

form, as the recombinant proteins are aggregated as inclusion bodies, which need to be solubilised (Clark, 2001). Generally optimization of IPTG concentration, growth temperature (after induction) and incubation time brings the protein into the soluble form (Prasad et al., 2011). Techniques such as sizeexclusion chromatography (Li et al., 2004), dialysis and dilution (Marston, 1986; Tsumoto et al., 2003; Umetsu et al., 2003), zeolite absorbing systems (Nara et al., 2009), reversed micelle systems (Sakono et al., 2004), microfluidic chips (Jahn et al., 2007) and the natural GroEL-GroES chaperone system (Zhi et al., 1992) could be used in soluble expression of recombinant proteins. Other problems include codon bias and lack of post translational machinery in E. coli (Gustafsson et al., 2004; Sahdev et al., 2008). The latter can be overcome by cloning the gene of interest in eukaryotic hosts such as Saccharomyces cerevisiae and $P$. pastoris. In this case, protein is expressed extracellularly, hence, we are saved from the energy intensive step of breaking the cells in disruptors or sonicators. Codon optimization also results in faster translation rates. $\alpha-\mathrm{CA}$ from Dunaliella species was codon optimized and effectively expressed in E. coli, which was used for biosequestration of $\mathrm{CO}_{2}$ (Kanth et al., 2012). A synthetic $\alpha$-CA (HC-aCA) from Hahella chejuensis was cloned and expressed (Ki et al., 2013). The codon-optimized carbonic anhydrase gene of thermophilic Persephonella marina EX-H1 (PMCA) was expressed and characterized. The removal of the signal peptide resulted in 5-fold enhancement of CA (Kanth et al., 2014). 


\section{Role of Metagenomics in CCS Technologies}

The advent of metagenomics has permitted discovery of numerous microorganisms from extreme environments, which could be of biotechnological interest. Metagenomics analysis has revealed the presence of CA encoding genes in the Indian Ocean viral metagenome (Williamson et al., 2012). Jones et al. (2012) showed the existence of RuBisCo and CA gene clusters in the Acidithiobacillus, an extremely acidophilic sulfur-oxidizing biofilm by community genome analysis. Microarray data of a metagenome of acid mine drainage also showed the presence of CA encoding genes along with the RuBisCo gene clusters (Guo et al., 2013). Three gene copies were identified which encoded CA in the metagenome of the marine ammonium oxidizing bacteria (van de Vossenberg et al., 2003). The metagenomes of the serpentinite-hosted Lost City hydrothermal field and Mid-Atlantic Ridge also indicated the presence of CA encoding genes. These metagenomes were found to be similar to the genome of Thiomicrospira crunogena XCL-2, an isolate from a basalt-hosted hydrothermal vent in the Pacific Ocean (Brazelton and Baross, 2010). Microorganisms exhibit great potential as bioindicators to detect leakages from $\mathrm{CO}_{2}$ storage projects and for that metagenomics becomes handy. Metagenomics and high throughput screen (HTS) methods can also be utilized for studying the effect of environmental changes on microbial communities at the CCS sites (Caporaso et al., 2012; Håvelsrud et al., 2012, 2013; Howe et al., 2014). Information about amplicons and metagenomes helps in establishing a CCS monitoring approach, which could even be useful in the detection of $\mathrm{CO}_{2}$ leaks (Noble et al., 2012). The use of HTS has already been found to be effective in evaluating the response of in situ bacterial populations to increased $\mathrm{CO}_{2}$, and matching community shifts to metabolic potential (Mu et al., 2014). The metagenomic approach along with appropriate bioinformatics tools makes the system competent. Metagenomics can thus be used as a biosensor for monitoring the CCS sites efficiently (Hicks et al., 2017).

\section{Utilization of Immobilized CA in CCSU}

Immobilization strategies are necessary so that the enzyme can be recycled number of times. Their stability can be enhanced by various immobilization techniques. Immobilization has long been used as an approach for increasing the stability of mesophilic enzymes. There are several reports of immobilization of mesophilic CAs. These CAs have been proved to be more efficient than the free enzymes for $\mathrm{CO}_{2}$ capture. CAs from P. fragi, Bacilllus pumilus, and Micrococcus lylae have been immobilized on chitosan and surfactant-modified silylated chitosan beads (Prabhu et al., 2009; Wanjari et al., 2011); these displayed enhanced $\mathrm{CO}_{2}$ hydration capacity. Chitosan is made of glucosamine and acetyl glucosamine units. The functional groups present on chitosan are amino and hydroxyl groups which are required for enzyme immobilization. The enzyme is adsorbed on the surface of chitosan beads. Immobilization of CAs also improved their thermal stabilities, for e.g., the immobilized CA retained at least $60 \%$ of the initial activity after 90 days at $50^{\circ} \mathrm{C}$ compared to about $30 \%$ for their free counterparts under the same conditions. The CAs also exhibit a high stability in the presence of inhibitors upon immobilization (Prabhu et al., 2009; Kanbar and Ozdemir, 2010). $\mathrm{CaCO}_{3}$ precipitation rate doubled in a period of $5 \mathrm{~min}$ when pure CA from $P$. fragi was immobilized by adsorption on chitosan beads in comparison with the free enzyme (Wanjari et al., 2012; Yadav et al., 2012). Immobilization of CAs on several other matrices such as ordered mesoporous aluminosilicate, octa(aminophenyl)silsesquioxanefunctionalized $\mathrm{Fe}_{3} \mathrm{O}_{4} / \mathrm{SiO}_{2}$ nanoparticles, silica nanoparticles and by single/multiple attachments to polymers deposited on $\mathrm{Fe}_{3} \mathrm{O}_{4}$ particles was also attempted (Sharma et al., 2011; Rayalu et al., 2012). CA immobilized on ordered mesoporous aluminosilicate exhibited $\mathrm{CO}_{2}$ sequestration efficiency of $16.14 \mathrm{mg}$ of $\mathrm{CaCO}_{3} / \mathrm{mg} \mathrm{CA}$ as compared to that of free enzyme which sequesters $33.08 \mathrm{mg}$ of $\mathrm{CaCO}_{3} / \mathrm{mg} \mathrm{CA}$. Immobilized CA even showed enhanced stability and retained $67 \%$ of initial activity even after six cycles (Yadav et al., 2011). Kinetics of the immobilized CAs (immobilized on ordered mesoporous aluminosilicate) were studied and compared with that of the free enzyme by Yadav et al. (2010). The $K \mathrm{~m}, V \max$, and $\mathrm{k}_{\mathrm{cat}}$ values of the immobilized enzyme were $0.158 \mathrm{mM}, 2.307 \mu$ mole $\min ^{-1} \mathrm{ml}^{-1}$, and $1.9 \mathrm{~s}^{-1}$, and these for free CA were 0.876 $\mathrm{mM}, 0.936 \mu$ mole $\mathrm{min}^{-1} \mathrm{ml}^{-1}$, and $2.3 \mathrm{~s}^{-1}$, respectively (Yadav et al., 2010). A high $\mathrm{CO}_{2}$ sequestration and improved stability have been achieved when CA was immobilized on core-shell CA-chitosan nanoparticles (SEN-CA; Rayalu et al., 2012). Ssp CA was immobilized on solid matrix made of silica particles (silanized Sipernat ${ }^{\circledR} 22$ particles). Enzyme-carrier covalent bonding was adopted as immobilization technique and it was observed that the enzyme stability and activity increased on immobilization. Immobilization of this CA in polyutherane foam also exhibited enhanced stability. The immobilized CA (PU-SspCA) showed exceptional thermostability for very long duration even at $70^{\circ} \mathrm{C}$. The $\mathrm{CO}_{2}$ absorption capacity of PUSspCA was verified in a three phase trickled bed bioreactor which mimics the post-combustion processes in a thermal power plant. The three-phase reactor was filled with shredded foam with PU-SspCA. The gas mixture $\left(\mathrm{CO}_{2} / \mathrm{N}_{2}\right)$ was fed from both the sides (i.e., concurrent and countercurrent). Increasing the flow rate of water and decreasing the $\mathrm{CO}_{2}$ flow rate also greatly improved $\mathrm{CO}_{2}$ capture in these reactors. SspCA showed good $\mathrm{CO}_{2}$ capture performance when the PU-SspCA-shredded foam was used in the bioreactor (Migliardini et al., 2014). Concerted efforts are needed to develop CA immobilization techniques that allow reuse of the enzyme 100-500 times with sustained activity. Immobilization can also lead to unwanted release of enzyme on surface of the reactor. In order to overcome this problem, some novel immobilization techniques have been developed using $\gamma-$ CA from P. horikoshii and M. thermophila (Salemme and Weber, 2014). The immobilization techniques allowed the development of $\gamma$-CA nanoassemblies (Salemme and Weber, 2014). An immobilization sequence was added at amino- or carboxyterminus which aided in proper and reversible immobilization of $\gamma$-CA to the functionalized surface. Gas-liquid membrane contractors are also emerging as potential bio reactors for using CAs for $\mathrm{CO}_{2}$ capture. Iliuta and Iliuta (2017) has demonstrated a novel, cost effective and environmentally friendly approach for 
$\mathrm{CO}_{2}$ capture by immobilizing $\mathrm{CA}$ in a hollow-fiber membrane bioreactor $(H F M B)$ by multiscale steady-state model, under partially liquid-filled and gas-filled membrane pores conditions.

Nanoparticles are also widely used for immobilization of enzymes due to their unique size and physical properties. The immobilization of enzymes on nanoparticles (NPs) offers high surface area and may lead to reduction in protein unfolding, improvement in storage stability and performance (Laurent et al., 2008; Xu et al., 2014). Iron mangnetic nanoparticles (MNPs) are being synthesized with various surface modifications in order to use them for immobilizing protein/enzyme. The CA from $B$. pumilus TS1 was immobilized successfully on chitosan stabilized iron MNPs (Yadav et al., 2012). Silanization of iron MNPs is being widely used for surface modifications of iron MNPs. It is also very easy and cost effective technique, which can be carried out simply in aqueous or organic media at moderate temperatures (Xu et al., 2014). Faridi et al. (2017) showed that even after 22 cycles of reuse, recombinant $\alpha$-CA (rBhCA) from $B$. halodurans TSLV1 immobilized on silanized iron MNPs (rBhCASi-MNPs) lost only $50 \%$ of activity. Nickel nanoparticles have been successfully used as a direct catalyst for $\mathrm{CO}_{2}$ hydration reaction for assessing their application in $\mathrm{CO}_{2}$ mineralization (Bhaduri et al., 2015).

\section{Other Applications of Carbonic Anhydrases}

Apart from their utility in CCSU, the CAs have some other applications too as discussed below:

\section{Carbonic Anhydrase in Formation of Bioconcrete}

Biomineralization by bacteria facilitates the development of bioconcrete, wherein calcium carbonate is formed by the metabolic activity of microorganisms, which involves a series of complex reactions directed mainly by urease and carbonic anhydrase enzymes (Castro et al., 2016). The activity of urease, CA, concentration of calcium and $\mathrm{pH}$ are very important in bioconcrete formation (Achal and Mukherjee, 2015).

\section{Artificial Lungs}

This equipment helps to overcome respiratory problems. The major drawback of this technique is the insufficient transfer of $\mathrm{CO}_{2}$ per square inch through the polymeric hollow fiber membranes (HFM). CAs can be utilized by immobilizing on HFM in order to increase the rate of $\mathrm{CO}_{2}$ transfer. CAs can, therefore, be used in developing small artificial lungs, which could be efficiently utilized within the human body (Kaar et al., 2007).

\section{Biosensors}

HCA II based biosensors have been employed to check the toxic effects of zinc on marine life (Thompson and Jones, 1993; Rout and Das, 2003; Muyssen et al., 2006). Many researchers are attempting to develop biosensor variants for other transition metals (Thompson et al., 2000, 2002; Frederickson et al., 2006; Bozym et al., 2008; Wang et al., 2011; McCranor et al., 2012).

\section{Pharmalogical Considerations}

CAs can be incorporated into stimuli-triggered drug delivery systems which utilize $\mathrm{CO}_{2}$, bicarbonate or $\mathrm{pH}$ changes as signaling molecules. This can improve the efficiency of these antidote based delivery systems (Satav et al., 2010).

\section{Blood Substitutes}

The current blood substitutes have inadequate $\mathrm{CO}_{2}$ removal rate, which leads to coma or death. CAs can be utilized along with catalase (CAT) and superoxide dismutase (SOD into the PolySFHb substitute (PolySFHb-SOD-CAT-CA) in order to overcome this limitation (Bian et al., 2011).

\section{CONCLUSIONS AND FUTURE PERSPECTIVES}

CAs are a class of enzymes which are essential for the survival of living beings. This enzyme not only helps in our metabolic activities but also aids in the protection of Mother Nature. Due to anthropogenic activities, the nature is getting destroyed day by day. Global warming is having its toll on the climate and weather. Carbonic anhydrase can aid in tackling the future catastrophes due to global warming. Unfortunately the CCS and biomineralization techniques are either in the lab stage or pilot plant stage. Researchers are constantly attempting to address a few of the key issues related to this technology, thus, it has become quite difficult to generate a public consensus on CCS technology. The technology needs to be ameliorated. We are also not able to bring down the carbon emissions as fossil fuels are (also will be in near future) the main energy source which drives today's world. Although much is known about CAs, the current metadata reveals the presence of many CA genes in the extreme realms of earth which are waiting to be discovered. These are mostly from unculturable microbes. Bioinformatics tools have been useful in identifying different CA encoding genes. Once identified, they can be easily cloned and expressed in different microbial hosts for studying their novel properties and utility in $\mathrm{CO}_{2}$ biomineralization. Currently the unexplored data is so vast that we may discover a few novel classes of CAs in addition to the known six classes in future. CAs from polyextremophilic microbial sources have already been tried for CCS related strategies. Enzyme immobilization techniques permit the repeated use of the enzyme and designing continuously operating reactors. We need to improve the CA immobilization technology so that it becomes cost effective and readily accepted by people. Further research efforts are called for developing highly efficient and robust CAs, efficient immobilization techniques and designing continuously operating reactors for cost effective biomimetic carbon sequestration. 


\section{AUTHOR CONTRIBUTIONS}

All authors listed have made a substantial, direct and intellectual contribution to the work, and approved it for publication.

\section{REFERENCES}

Aaron, D., and Tsouris, C. (2005). Separation of $\mathrm{CO}_{2}$ from flue gas: a review. Sep. Sci. Technol. 40, 321-348. doi: 10.1081/SS-200042244

Achal, V., and Mukherjee, A. (2015). Review of microbial precipitation for sustainable construction. Constr. Build. Mater. 93, 1224-1235. doi: 10.1016/j.conbuildmat.2015.04.051

Adams, M. R., Hurd, H. B., Lenhart, S., and Leary, N. (1998). Effects of global climate change on agriculture: an interpretative review. Clim. Res. 11, 19-30. doi: $10.3354 /$ cr011019

Alber, B. E., and Ferry, J. G. (1994). A carbonic anhydrase from the archaeon Methanosarcina thermophila. Proc. Nat. Acad. Sci. U.S.A. 91, 6909-6913. doi: 10.1073/pnas.91.15.6909

Alvizo, O., Nguyen, L. J., Savile, C. K., Bresson, J. A., Lakhapatri, S. L., Solis, E. O., et al. (2014). Directed evolution of an ultrastable carbonic anhydrase for highly efficient carbon capture from flue gas. Proc. Nat. Acad. Sci. U.S.A. 111, 16436-16441. doi: 10.1073/pnas.1411461111

Aspelund, A., Molnvik, M. J., and DeKoeijer, G. (2006). Ship transport of $\mathrm{CO}_{2}$, technical solutions and analysis of costs, energy utilization, energy efficiency and $\mathrm{CO}_{2}$ emissions. Chem. Eng. Res. Des. 84, 847-855. doi: 10.1205/cherd.5147

Badger, M. R., and Price, G. D. (2003). $\mathrm{CO}_{2}$ concentrating mechanisms in cyanobacteria: molecular components, their diversity and evolution. J. Exp. Bot. 54, 609-622. doi: 10.1093/jxb/erg076

Benson, S., Cook, P., Anderson, J., Bachu, S., Nimir, H. B., Basu, B., et al. (2005). "Underground geological storage," in IPCC Special Report on Carbon Dioxide Capture and Storage, eds B. Metz, O. Davidson, H. de Coninck, M. Loos, L. Meyer (Cambridge: Cambridge University Press), 195-277.

Berg, J. M., Tymoczko, J. L., and Stryer, L. (2002). Biochemistry 5th edn., New York, NY: W H Freeman.

Bhaduri, G. A., Alamiry, M. A., and Šiller, L. (2015). Nickel nanoparticles for enhancing carbon capture. J. Nanomater. 16:376. doi: 10.1155/2015/581785

Bhojiya, A. A., and Joshi, H. (2012). Isolation and characterization of zinc tolerant bacteria from Zawar mines Udaipur, India. IJEEM. 3, 239-242.

Bhown, A. S., and Freeman, B. C. (2011). Analysis and status of post-combustion carbon dioxide capture technologies. Environ. Sci. Technol. 45, 8624-8632. doi: 10.1021/es104291d

Bian, Y., Rong, Z., and Chang, T. M. S. (2011). Polyhemoglobin-superoxide dismutase-catalase-carbonic anhydrase: a novel biotechnology-based blood substitute that transports both oxygen and carbon dioxide and also acts as an antioxidant. Artif. Cells. Blood. Substit. Immobil. Biotechnol. 39, 127-136. doi: 10.3109/10731199.2011.581052

Boone, C. D., Gill, S., Habibzadegan, A., and McKenna, R. (2013). Carbonic anhydrase: an efficient enzyme with possible global implications. Int. J. Chem. Eng. 2013, 1-7. doi: 10.1155/2013/813931

Boot-Handford, M. E., Abanades, J. C., Anthony, E. J., Blunt, M. J., Brandani, S., Mac Dowell, N., et al. (2014). Carbon capture and storage update. Energy Environ. Sci. 7, 130-189. doi: 10.1039/C3EE42350F

Bose, H., and Satyanarayana, T. (2016). Suitability of the alkalistable carbonic anhydrase from a polyextremophilic bacterium Aeribacillus pallidus TSHB1 in biomimetic carbon sequestration. Bioprocess. Biosyst. Eng. 39, 1515-1525. doi: 10.1007/s00449-016-1627-4

Bose, H., and Satyanarayana, T. (2017). Utility of thermo-alkali-stable $\gamma$-CA from polyextremophilic bacterium Aeribacillus pallidus TSHB1 in biomimetic sequestration of $\mathrm{CO} 2$ and as a virtual peroxidase. Environ. Sci. Pollut. Res. 24, 10869-10884. doi: 10.1007/s11356-017-8739-5

Bourais, I., Maliki, S., Mohammadi, H., and Amine, A. (2017). Investigation of sulfonamides inhibition of carbonic anhydrase enzyme using multiphotometric and electrochemical techniques. Enzyme Microb. Technol. 96, 23-29. doi: 10.1016/j.enzmictec.2016.09.007

\section{ACKNOWLEDGMENTS}

We wish to thank University Grants Commission, Govt. of India, New Delhi for awarding Faculty Fellowship to one of us (TS) while writing this review.

Bozym, R., Hurst, T. K., Westerberg, N., Stoddard, A., and Fierke, C. A., Frederickson, C. J., et al. (2008). Determination of zinc using carbonic anhydrase-based fluorescence biosensors. Meth. Enzymol. 450, 287-309. doi: 10.1016/S0076-6879(08)03414-9

Brazelton, J. W., and Baross, A. J. (2010). Metagenomic comparison of two Thiomicrospira lineages inhabiting contrasting deep-sea hydrothermal environments. PLoS ONE 5:e13530. doi: 10.1371/journal.pone.0013530

Buhre, B. J. P., Elliott, L. K., Sheng, C. D., Gupta, R. P., and Wall, T. F. (2005). Oxy-fuel combustion technology for coal-fired power generation. Prog. Energy Combust. Sci. 31, 283-307. doi: 10.1016/j.pecs.2005.07.001

Burghout, P., Vullo, D., Scozzafava, A., Hermans, P. W., and Supuran, C. T. (2011). Inhibition of the $\beta$-carbonic anhydrase from Streptococcus pneumoniae by inorganic anions and small molecules: toward innovative drug design of antiinfectives? Bioorg. Med. Chem. 19, 243-248. doi: 10.1016/j.bmc.2010.1 1.031

Cabiscol, E., and Levine, R. L. (1995). Carbonic anhydrase III. Oxidative modification in vivo and loss of phosphate activity during aging. J. Biol. Chem. 270, 14742-14747. doi: 10.1074/jbc.270.24.14742

Capasso, C., De Luca, V., Carginalea, V., Caramuscioc, P., Cavalheiroc, C. F., Canniod, R., et al. (2012). Characterization and properties of a new thermoactive and thermostable carbonic anhydrase. Chem. Eng. 27, 271-276. doi: 10.3303/CET1227046

Caporaso, J. G., Lauber, C. L., Walters, W. A., Berg-Lyons, D., Huntley, J., Fierer, N., et al. (2012). Ultra-high-throughput microbial community analysis on the Illumina HiSeq and MiSeq platforms. ISME. J. 6, 1621-1624. doi: 10.1038/ismej.2012.8

Carta, F., Aggarwal, M., Maresca, A., Scozzafava, A., McKenna, R., and Supuran, C. T. (2012). Dithiocarbamates: a new class of carbonic anhydrase inhibitors. Crystallographic and kinetic investigations. Chem. Commum. 48, 1868-1870. doi: $10.1039 /$ c2cc16395k

Castro, M. J., and Lopez, C. E., Narayanasamy, R., Marszalek, J. E., LuevanosEscareno, M. P., Fajardo, G. J., et al. (2016). Potential of enzymes (urease \& carbonic anhydrase). Chim. Oggi. Chem. 34:4.

Chirica, L. C., Elleby, B., and Lindskog, S. (2001). Cloning, expression and some properties of $\alpha$-carbonic anhydrase from Helicobacter pylori. Biochim. Biophys. Acta 1544, 55-63. doi: 10.1016/S0167-4838(00)00204-1

Chirică, L. C., Elleby, B., Jonsson, B. H., and Lindskog, S. (1997). The complete sequence, expression in Escherichia coli, purification and some properties of carbonic anhydrase from Neisseria gonorrhoeae. FEBS. J. 244, 755-760. doi: 10.1111/j.1432-1033.1997.00755.x

Ciullo, P. A. (1996). Industrial Minerals and their Uses: A Handbook and Formulatory. New Jersey: William Andrew Publishing/Noyes.

Clark, E. D. B. (2001). Protein refolding for industrial processes. Curr. Opin. Biotechnol. 12, 202-207. doi: 10.1016/S0958-1669(00)00200-7

$\mathrm{CO}_{2}$ Solutions Inc. (2012). Available online at: www.co2solutions.com/en/the-process (Accessed January 11, 2017).

Coker, J. A. (2016). Extremophiles and biotechnology: current uses and prospects. F1000Research 5:F1000 Faculty Rev-396. doi: 10.12688/f1000research.7432.1

Cronk, J. D., Endrizzi, J. A., Cronk, M. R., O'neill, J. W., and Zhang, K. Y. (2001). Crystal structure of $E$. coli $\beta$-carbonic anhydrase, an enzyme with an unusual pH-dependent activity. Protein Sci. 10, 911-922. doi: 10.1110/ps.46301

Cronk, J. D., Rowlett, R. S., Zhang, K. Y. J., Tu, C., Endrizzi, J. A., Lee, J., et al. (2006). Identification of a novel noncatalytic bicarbonate binding site in eubacterial $\beta$-carbonic anhydrase. Biochemistry 45, 4351-4361. doi: 10.1021/bi052272q

Da Silva, E. F., and Booth, A. M. (2013). Emissions from post-combustion $\mathrm{CO}_{2}$ capture plants. Environ. Sci. Technol. 47, 659-660. doi: 10.1021/es305111u

Daigle, R. M. E., and Fradette, S. (2014). Techniques for $\mathrm{CO}_{2}$ Capture Using Sulfurihydrogenibium sp. Carbonic Anhydrase. Patent WO 2014066999 A1. 
De Luca, V., Vullo, D., Scozzafava, A., Carginale, V., Rossi, M., Supuran, C. T., et al. (2013). An $\alpha$-carbonic anhydrase from the thermophilic bacterium Sulphurihydrogenibium azorense is the fastest enzyme known for the $\mathrm{CO}_{2}$ hydration reaction. Bioorg. Med. Chem. 21, 1465-1469. doi: 10.1016/j.bmc.2012.09.047

De Simone, G., Monti, S. M., Alterio, V., Buonanno, M., De Luca, V., Rossi, M., et al. (2015). Crystal structure of the most catalytically effective carbonic anhydrase enzyme known, SazCA from the thermophilic bacterium Sulfurihydrogenibium azorense. Bioorg. Med. Chem. Lett. 25, 2002-2006. doi: 10.1016/j.bmcl.2015.02.068

Del Prete, S., Isik, S., Vullo, D., De Luca, V., Carginale, V., Scozzafava, A., et al. (2012). DNA cloning, characterization, and inhibition studies of an $\alpha$-carbonic anhydrase from the pathogenic bacterium Vibrio cholerae. J. Med. Chem. 55, 10742-10748. doi: 10.1021/jm301611m

Del Prete, S., Vullo, D., Fisher, G. M., Andrews, K. T., Poulsen, S. A., Capasso, C., et al. (2014). Discovery of a new family of carbonic anhydrases in the malaria pathogen Plasmodium falciparum-The $\eta$-carbonic anhydrases. Bioorg. Med. Chem. Lett. 24, 4389-4396. doi: 10.1016/j.bmcl.2014.08.015

Di Fiore, A., Alterio, V., Monti, S. M., De Simone, G., and D'Ambrosio, K. (2015). Thermostable carbonic anhydrases in biotechnological applications. Int. J. Mol. Sci. 16, 15456-15480. doi: 10.3390/ijms160715456

Di Fiore, A., Capasso, C., De Luca, V., Monti, S. M., Carginale, V., and Supuran, C. T. (2013). X-ray structure of the firstextremo- $\alpha$-carbonic anhydrase', a dimeric enzyme from the thermophilic bacterium Sulfurihydrogenibium yellowstonense YO3AOP1. Acta. Crystallogr. Sect. D. 69, 1150-1159. doi: 10.1107/S0907444913007208

Dreybodt, W., Eisenlohr, L., Madry, B., and Ringer, S. (1997). Precipitation kinetics of calcite in the system $\mathrm{CaCO}_{3}-\mathrm{H}_{2} \mathrm{O}-\mathrm{CO}_{2}$. Geochim. Cosmochim. Acta. 61, 3987-3904.

Druckenmiller, M. L., and Maroto-Valer, M. M. (2005). Carbon sequestration using brine of adjusted $\mathrm{pH}$ to form mineral carbonates. Fuel Process. Technol. 86, 1599-1614. doi: 10.1016/j.fuproc.2005.01.007

Dutreuil, S., Bopp, L., and Tagliabue, A. (2009).Impact of enhanced vertical mixing on marine biogeochemistry: lessons for geo-engineering and natural variability. Biogeosci. Discuss. 6, 901-912. doi: 10.5194/bg-6-901-2009

Faridi, S., and Satyanarayana, T. (2016b). Characteristics of recombinant $\alpha$ carbonic anhydrase of polyextremophilic bacterium Bacillus halodurans TSLV1. Int. J. Biol. Macromol. 89, 659-668. doi: 10.1016/j.ijbiomac.2016.05.026

Faridi, S., and Satyanarayana, T. (2015). "Bioconversion of industrial $\mathrm{CO}_{2}$ emissions into utilizable products," in Industrial Waste Management, ed R. Chandra (New York, NY: CRC Press), 111-156.

Faridi, S., and Satyanarayana, T. (2016a). Novel alkalistable $\alpha$-carbonic anhydrase from the polyextremophilic bacterium Bacillus halodurans: characteristics and applicability in flue gas $\mathrm{CO}_{2}$ sequestration. Environ. Sci. Pollut. Res. 23, 15236-15249. doi: 10.1007/s11356-016-6642-0

Faridi, S., Bose, H., and Satyanarayana, T. (2017). Utility of immobilized recombinant carbonic anhydrase of Bacillus halodurans TSLV1 on the surface of modified iron magnetic nanoparticles in carbon sequestration. Energy Fuels 31, 3002-3009. doi: 10.1021/acs.energyfuels.6b02777

Farrell, A. (2011). Carbon Dioxide Storage in Stable Carbonate Minerals. University of Maryland Geology, Basalt Laboratory Studies of Interest to Carbon Capture and Storage, Advisor MN Evans.

Favre, N., Christ, M. L., and Pierre, A. C. (2009). Biocatalytic capture of $\mathrm{CO}_{2}$ with carbonic anhydrase and its transformation to solid carbonate. J. Mol. Catal. B. Enzym. 60, 163-170. doi: 10.1016/j.molcatb.2009.04.018

Fisher, Z., Boone, C. D., Biswas, S. M., Venkatakrihnan, B., Aggarwal, M., and Tu, C., et al. (2012). R. Kinetic and structural characterization of thermostabilized mutants of human carbonic anhydrase II. Protein Eng. Des. Sel. 25, 347-355. doi: 10.1093/protein/gzs027

Floyd, W. C. III., Baker, S. E., Valdez, C. A., Stolaroff, J. K., Bearinger, J. P., Satcher, J. H. Jr., et al. (2013). Evaluation of a carbonic anhydrase mimic for industrial carbon capture. Environ. Sci. Technol. 47, 10049-10055. doi: 10.1021/es40 $1336 f$

Frederickson, C. J., Giblin, L. J., Krężel, A., McAdoo, D. J., Muelle, R. N., Zeng, Y., et al. (2006). Concentrations of extracellular free zinc (pZn) e in the central nervous system during simple anesthetization, ischemia and reperfusion. Exp. Neurol. 198, 285-293. doi: 10.1016/j.expneurol.2005.08.030
Frost, S. C., and McKenna, R. (2013). Carbonic Anhydrase: Mechanism, Regulation, Links to Disease, and Industrial Applications. Dordrecht: Springer Science \& Business Media.

Fujita, N., Mori, H., Yura, T., and Ishihama, A. (1994). Systematic sequencing of the Escherichia coli genome: analysis of the 2.4-4.1 $\mathrm{min}(110,917-193,643 \mathrm{bp})$ region. Nucleic Acids Res. 22, 1637-1639. doi: 10.1093/nar/22.9.1637

Gao, L., Fang, M., Li, H., and Hetland, J. (2014). Cost analysis of $\mathrm{CO}_{2}$ transportation: case study in China. Energy Procedia 4, 5974-5981. doi: 10.1016/j.egypro.2011.02.600

Gill, S. R., Fedorka-Cray, P. J., Tweten, R. K., and Sleeper, B. P. (1984). Purification and properties of the carbonic anhydrase of Rhodospirillum rubrum. Arch. Microbiol. 138, 113-118. doi: 10.1007/BF00413010

Guo, X., Yin, H., Cong, J., Dai, Z., Liang, Y., and Liua, X. (2013). RubisCO gene clusters found in a metagenome microarray from acid mine drainage. Appl. Environ. Microbiol. 79, 2019-2026. doi: 10.1128/AEM.03400-12

Gustafsson, C., Govindarajan, S., and Minshull, J. (2004). Codon bias and heterologous protein expression. Trends Biotechnol. 22, 346-353. doi: 10.1016/j.tibtech.2004.04.006

Han, K. H., Chun, Y. H., De Castro Pimentel Figueiredo, B., Soriani, F. M., Savoldi, M., Almeida, A., et al. (2010). The conserved and divergent roles of carbonic anhydrases in the filamentous fungi Aspergillus fumigatus and Aspergillus nidulans. Mol. Microbiol. 75, 1372-1388. doi: 10.1111/j.1365-2958.2010.07152.x

Hart, A., and Gnanendran, N. (2009). Cryogenic $\mathrm{CO}_{2}$ capture in natural gas. Energy Procedia 1, 697-706. doi: 10.1016/j.egypro.2009.01.092

Håvelsrud, O. E., Haverkamp, T. H., Kristensen, T., Jakobsen, K. S., and Rike, A. G. (2013). Metagenomics in $\mathrm{CO}_{2}$ monitoring. Energy Procedia 37, 4215-4233. doi: 10.1016/j.egypro.2013.06.324

Håvelsrud, O. E., Haverkamp, T. H., Kristensen, T., Jakobsen, K. S., and Rike, A. G. (2012). Metagenomic and geochemical characterization of pockmarked sediments overlaying the troll petroleum reservoir in the North Sea. BMC Microbiol. 12:203. doi: 10.1186/1471-2180-12-203

Haywood, H., Eyre, J., and Scholes, H. (2001). Carbon dioxide sequestration as stable carbonate minerals-environmental barriers. Environ. Geol. 41, 11-16. doi: $10.1007 / \mathrm{s} 002540100372$

Herzog, H. J. (1998). "Ocean sequestration of $\mathrm{CO}_{2}$ - an overview," in Fourth International Conference on Greenhouse Gas Control Technologies August 30 September 2. (Interlaken), 1-5.

Hewitson, K. S., Vullo, D., Scozzafava, A., Mastrolorenzo, A., and Supuran, C. T. (2012). Molecular cloning, characterization, and inhibition studies of a $\beta$ carbonic anhydrase from Malassezia globosa, a potential antidandruff target. J. Med. Chem. 55, 3513-3520. doi: 10.1021/jm300203r

Hicks, N., Vik, U., Taylor, P., Ladoukakis, E., Park, J., Kolisis, F., et al. (2017). Using prokaryotes for carbon capture storage. Trends Biotechnol. 35, 22-32. doi: 10.1016/j.tibtech.2016.06.011

Howe, A. C., Jansson, J. K., Malfatti, S. A., Tringe, S. G., Tiedje, J. M., and Brown, C. T. (2014). Tackling soil diversity with the assembly of large, complex metagenomes. Proc. Nat. Acad. Sci. U.S.A. 111, 4904-4909. doi: $10.1073 /$ pnas. 1402564111

Huang, S., Xue, Y., Sauer-Eriksson, E., Chirica, L., Lindskog, S., and Jonsson, B. H. (1998). Crystal structure of carbonic anhydrase from Neisseria gonorrhoeae and its complex with the inhibitor acetazolamide. J. Mol. Biol. 283, 301-310. doi: 10.1006/jmbi.1998.2077

Huijgen, W. J., Comans, R. N., and Witkamp, G. J. (2007). Cost evaluation of $\mathrm{CO}_{2}$ sequestration by aqueous mineral carbonation. Energy Convers. Manage. 48, 1923-1935. doi: 10.1016/j.enconman.2007.01.035

Iliuta, I., and Iliuta, M. C. (2017). Investigation of $\mathrm{CO}_{2}$ Removal by immobilized carbonic anhydrase enzyme in a hollow-fiber membrane bioreactor. AIChE J. 63, 2996-3007. doi: 10.1002/aic.15646

Innocenti, A., Hall, R. A., Schlicker, C., Scozzafava, A., Steegborn, C., Mühlschlegel, F. A., et al. (2009a). Carbonic anhydrase inhibitors. Inhibition and homology modeling studies of the fungal $\beta$-carbonic anhydrase from Candida albicans with sulfonamides. Bioorg. Med. Chem. Lett. 17, 4503-4509. doi: 10.1016/j.bmc.2009.05.002

Innocenti, A., Leewattanapasuk, W., Muhlschlegel, F. A., Mastrolorenzo, A., and Supuran, C. T. (2009b). Carbonic anhydrase inhibitors.Inhibition of the betaclass enzyme from the pathogenic yeast Candida glabrata with anions. Bioorg. Med. Chem. Lett. 19, 4802-4805. doi: 10.1016/j.bmcl.2009.06.048 
IPCC (2000) Special Report on Emissions Scenarios: A Special Report of Working Group III of the Intergovernmental Panel on Climate Change. New York, NY: Cambridge University Press.

IPCC (2013) Fourth assessment report: climate change (AR5) from IPCC. Available online at: http://ipcc.ch/publications_and_data/publications_and_ data_reports.shtml/; (Accessed March 2, 2017).

IPCC (Inter-governmental Panel on Climate Change) (2014) Climate Change Synthesis Report. Cambridge: Cambridge University Press.

Jahn, A., Vreeland, W. N., DeVoe, D. L., Locascio, L. E., and Gaitan, M. (2007). Microfluidic directed formation of liposomes of controlled size. Langmuir 23, 6289-6293. doi: 10.1021/la070051a

James, P., Isupov, M. N., Sayer, C., Saneei, V., Berg, S., Lioliou, M., et al. (2014). The structure of a tetrameric $\alpha$-carbonic anhydrase from Thermovibrio ammonificans reveals a core formed around intermolecular disulfides that contribute to its thermostability. Acta Crystallogr. Sect. D. 70, 2607-2618. doi: $10.1107 /$ S1399004714016526

Jo, B. H., Kim, I. G., Seo, J. H., Kang, D. G., and Cha, H. J. (2013). Engineered Escherichia coli with periplasmic carbonic anhydrase as a biocatalyst for $\mathrm{CO}_{2}$ sequestration. Appl. Environ. Microbiol. 79, 6697-6705. doi: 10.1128/AEM.02400-13

Jo, B. H., Park, T. Y., Park, H. J., Yeon, Y. J., Yoo, Y. J., and Cha, H. J. (2016). Enginering de novo disulfide bond in bacterial $\alpha$-type carbonic anhydrase for thermostable carbon sequestration. Sci. Rep. 6, 1-9. doi: 10.1038/srep29322

Jo, B. H., Seo, J. H., and Cha, J. C. (2014). Bacterial extremo- $\alpha-$ carbonic anhydrases from deep-sea hydrothermal vents as potential biocatalysts for $\mathrm{CO}_{2}$ sequestration. J. Mol. Catal. B. Enzym. 109, 31-39. doi: $10.1016 /$ j.molcatb.2014.08.002

Jones, S. D., Albrecht, L. H., and Dawson, S. K. (2012). Community genomic analysis of an extremely acidophilic sulfur-oxidizing biofilm. ISME J. 6, 158-117. doi: 10.1038/ismej.2011.75

Joseph, P., Turtaut, F., Ouahrani-Bettache, S., Montero, J. L., Nishimori, I., Minakuchi, T., et al. (2010). Cloning, characterization, and inhibition studies of a $\beta$-carbonic anhydrase from Brucella suis. J. Med. Chem. 53, 2277-2285. doi: $10.1021 / \mathrm{jm} 901855 \mathrm{~h}$

Kaar, J. L., Oh, H. I., Russell, A. J., and Federspiel, W. J. (2007). Towards improved artificial lungs through biocatalysis. Biomaterials 28, 3131-3139. doi: 10.1016/j.biomaterials.2007.03.021

Kanbar, B., and Ozdemir, E. (2010). Thermal stability of carbonic anhydrase immobilized within polyurethane foam. Biotechnol. Prog. 26, 1474-1480. doi: $10.1002 / \mathrm{btpr} .452$

Kanth, B. K., Jun, S. Y., and Kumari, S. (2014). Highly thermostable carbonic anhydrase from Persephonella marina EX-H1: its expression and characterization for $\mathrm{CO}_{2}$ sequestration Applications. Proc. Biochem. 49, 2114-2121. doi: 10.1016/j.procbio.2014.10.011

Kanth, B. K., Min, K., Kumari, S., Jeon, H., Jin, E. S., Lee, J., et al. (2012). Expression and characterization of codon-optimized carbonic anhydrase from Dunaliella species for $\mathrm{CO}_{2}$ sequestration application. Appl. Biochem. Biotechnol. 167, 2341-2356. doi: 10.1007/s12010-012-9729-1

Kaur, S., Bhattacharya, A., Sharma, A., and Tripathi, A. K. (2012). "Diversity of microbial carbonic anhydrases, their physiological role and applications", in Microorganisms in Environmental Management: Microbes and Environment eds T. Satyanarayana, B. N. Johri, A. Prakash (New york, NY: Springer), 151-173.

Kheshgi, H., deConninck, H., and Kessels, J. (2012). Carbon dioxide capture and storage: seven years after the IPCC special report. Mitig. Adapt. Strat. Glob. Change 17, 563-567. doi: 10.1007/s11027-012-9391-5

Ki, M. R., Min, K., Kanth, B. K., Lee, J., and Pack, S. P. (2013). Expression, reconstruction and characterization of codon-optimized carbonic anhydrase from Hahella chejuensis for $\mathrm{CO}_{2}$ sequestration application. Bioprocess. Biosyst. Eng. 36, 375-381. doi: 10.1007/s00449-012-0788-z

Kim, I. G., Jo, B. H., Kang, D. G., Kim, C. S., Choi, Y. S., and Cha, H. J. (2012). Biomineralization-based conversion of carbon dioxide to calcium carbonate using recombinant carbonic anhydrase. Chemosphere 87, 1091-1096. doi: 10.1016/j.chemosphere.2012.02.003

Knudsen, J. N., Jensen, J. N., Vilhelmsen, P. J., and Biede, O. (2009). Experience with $\mathrm{CO}_{2}$ capture from coal flue gas in pilot-scale: testing of different amine solvents. Energy Procedia 1, 783-790. doi: 10.1016/j.egypro.2009.01.104

Kumar, V., and Satyanarayana, T. (2014). Production of thermo-alkali-stable xylanase by a novel polyextremophilic Bacillus halodurans TSEV1 in cane molasses medium and its applicability in making whole wheat bread. Bioprocess. Biosyst. Eng. 37, 1043-1053. doi: 10.1007/s00449-013-1075-3

Kupriyanova, E. V., Sinetova, M. A., Markelova, A. G., Allakhverdiev, S. I., Los, D. A., and Pronina, N. A. (2011). Extracellular $\beta$ _class carbonic anhydrase of the alka-liphilic cyanobacterium Microcoleus chthonoplastes. J. Photochem. Photobiol. B. 103, 78-86. doi: 10.1016/j.jphotobiol.2011.01.021

Kupriyanova, E., Villarejo, A., Markelova, A., Gerasi-menko, L., Zavarzin, G., Samuelsson, G., et al. (2007). Extracellular carbonic anhydrases of the stromatolite_forming cyanobacterium Microcoleus chthonoplastes. Microbiology (SGM) 153, 1149-1156. doi: 10.1099/mic.0.2006/003905-0

Lane, T. W., and Morel, F. M. M. (2000). A biological function for cadmium in marine diatoms. Proc. Nat. Acad. Sci.U.S.A. 97, 4627-4631. doi: $10.1073 /$ pnas.090091397

Lapointe, M., MacKenzie, T. D. B., and Morse, D. (2008). An external $\delta$ carbonic anhydrase in a free-living marine dinoflagellate may circumvent diffusion-limited carbon acquisition. Plant. Physiol. 147, 1427-1436. doi: 10.1104/pp.108.117077

Laurent, S., Forge, D., Port, M., Roch, A., Robic, C., Vander Elst, L., et al. (2008). Magnetic iron oxide nanoparticles: synthesis, stabilization, vectorization, physicochemical characterizations, and biological applications. Chem. Rev. 108, 2064-2110. doi: $10.1021 /$ cr068445e

Leung, D. Y., Caramanna, G., and Maroto-Valer, M. M. (2014). An overview of current status of carbon dioxide capture and storage technologies. Renew. Sustainable Energy Rev. 39, 426-443. doi: 10.1016/j.rser.2014.07.093

Li, M., Su, Z. G., and Janson, J. C. (2004). In vitro protein refolding by chromatographic procedures. Protein. Expr. Purif. 33, 1-10. doi: 10.1016/j.pep.2003.08.023

Li, M., Zhu, X., Wilkinson, S., Huang, M., and Achal, V. (2016). Complete genome sequence of carbonic anhydrase producing Psychrobacter sp. SHUES1. Front. Microbiol. 7:1442. doi: 10.3389/fmicb.2016.01442

Lindskog, S., and Coleman, J. E. (1973). The catalytic mechanism of carbonic anhydrase. Proc. Nat. Acad. Sci. U.S.A. 70, 2505-2508. doi: 10.1073/pnas.70.9.2505

Liu, N., Bond, G. M., Abel, T. A., McPherson, B. J., and Stringer, J. (2005). Biomimetic sequestration of $\mathrm{CO}_{2}$ in carbonate form: role of produced waters and other brines. Fuel Process. Technol. 86, 1615-1625. doi: 10.1016/J.FUPROC.2005.01.008

Lomelino, C., and McKenna, R. (2016). Carbonic anhydrase inhibitors: a review on the progress of patent literature (2011-2016). Expert Opin. Ther. Pat. 26, 947-956. doi: 10.1080/13543776.2016.1203904

MacAuley, S. R., Zimmerman, S. A., Apolinario, E. E., Evilia, C., Hou, Y. M., Ferry, J. G., et al. (2009). The archetype $\gamma$-class carbonic anhydrase (cam) contains iron when synthesized in vivo. Biochemistry 48, 817-819. doi: $10.1021 /$ bi802246s

Marston, F. A. O. (1986). The purification of eukaryotic polypeptides synthesized in Escherichia coli. Biochem. J. 240, 1-12. doi: 10.1042/bj2400001

McCranor, B. J., Bozym, R. A., Vitolo, M. I., Fierke, C. A., Bambrick, L., Polster, B. M., et al. (2012). Quantitative imaging of mitochondrial and cytosolic free zinc levels in an in vitro model of ischemia/reperfusion. J. Bioenerg. Biomembr. 44, 253-263. doi: 10.1007/s10863-012-9427-2

Medina-Puche, L., Castello, M. J., Canet, J. V., Lamilla, J., Colombo, L. M., and Tornero, P. (2017). B-carbonic anhydrases play a role in salicylic acid perception in Arabidosis. PLoS ONE 12:e0181810. doi: 10.1371/journal.pone. 0181820

Merlin, C., Masters, M., McAteer, S., and Coulson, A. (2003). Why is carbonic anhydrase essential to Escherichia coli? J. Bacteriol. 185, 6415-6424. doi: 10.1128/JB.185.21.6415-6424.2003

Mesbah, N. M., and Wiegel, J. (2012). Life under multiple extreme conditions: diversity and physiology of the halophilic alkalithermophiles. Appl. Environ. Microbiol. 78, 4074-4082. doi: 10.1128/AEM.00050-12

Mete, E., Comez, B., Inci Gul, H., Gulcin, I., and Supuran, C. T. (2016). Synthesis and carbonic anhydrase inhibitory activities of new thienylsubstituted pyrazoline benzenesulfonamides. J. Enzyme Inhib. Med. Chem. 31, 1-5. doi: $10.1080 / 14756366.2016 .1181627$

Migliardini, F., De Luca, V., Carginale, V., Rossi, M., Corbo, P., Supuran, C. T., et al. (2014). Biomimetic $\mathrm{CO}_{2}$ capture using a highly thermostable bacterial $\alpha$-carbonic anhydrase immobilized on a polyurethane foam. J. Enzyme. Inhib. Med. Chem. 29, 146-150. doi: 10.3109/14756366.2012.761608 
Minakuchi, T., Nishimori, I., Vullo, D., Scozzafava, A., and Supuran, C. T. (2009). Molecular cloning, characterization, and inhibition studies of the Rv1284 $\beta$-carbonic anhydrase from Mycobacterium tuberculosis with sulfonamides and a sulfamate. J. Med. Chem. 52, 2226-2232. doi: 10.1021/jm90 00488

Mirjafari, P., Asghari, K., and Mahinpey, N. (2007). Investigating the application of enzyme carbonic anhydrase for $\mathrm{CO}_{2}$ sequestration purposes. Ind. Eng. Chem. Res. 46, 921-926. doi: 10.1021/ie060287u

Mitchell, A. C., Dideriksen, K., Spangler, L. H., Cunningham, A. B., and Gerlach, R. (2010). Microbially enhanced carbon capture and storage by mineral-trapping and solubility-trapping. Environ. Sci. Technol. 44, 5270-5276. doi: $10.1021 /$ es $903270 \mathrm{w}$

Mogensen, E. G., Janbon, G., Chaloupka, J., Steegborn, C., Fu, M. S., Moyrand, F., et al. (2006). Cryptococcus neoformans senses $\mathrm{CO}_{2}$ through the carbonic anhydrase Can2 and the adenylyl cyclase Cac1. Eukaryot. Cell 5, 103-111. doi: 10.1128/EC.5.1.103-111.2006

Monti, S. M., De Simone, G., Dathan, N. A., Ludwig, M., Vullo, D., Scozzafava, A., et al. (2013). Kinetic and anion inhibition studies of a $\beta$-carbonic anhydrase (FbiCA 1) from the C4 plant Flaveria bidentis. Bioorg. Med. Chem. Lett. 23, 1626-1630. doi: 10.1016/j.bmcl.2013.01.087

More, R. H., McMillan, G. C., and Duff, G. L. (1946). The pathology of sulphonamide allergy in man. Am. J. Pathol. 22, 703-735.

Mu, A., Boreham, C., Leong, H. X., Haese, R., and Moreau, J. W. (2014). Changes in the deep subsurface microbial biosphere resulting from a field-scale $\mathrm{CO}_{2}$ geosequestration experiment. Front. Microbiol. 5:209. doi: $10.3389 /$ fmicb. 2014.00209

Muyssen, B. T., De Schamphelaere, K. A., and Janssen, C. R. (2006). Mechanisms of chronic waterborne Zn toxicity in Daphnia magna. Aquat. Toxicol. 77, 393-401. doi: 10.1016/j.aquatox.2006.01.006

Nara, T. Y., Togashi, H., Sekikawa, C., Kawakami, M., Yaginuma, N., Sakaguchi, K., et al. (2009). Use of zeolite to refold a disulfide-bonded protein. Colloids Surf. B. 68, 68-73. doi: 10.1016/j.colsurfb.2008.09.012

Nielsen, C. J., Herrmann, H., and Weller, C. (2012). Atmospheric chemistry and environmental impact of the use of amines in carbon capture and storage (CCS). Chem. Soc. Rev. 41, 6684-6704. doi: 10.1039/c2cs35059a

NOAA (2016) National Oceanic and Atmospheric Administration. Available online at: http://www.esrlnoaa.gov/gmd/ccgg/trends. (Accessed March 9, 2017).

NOAA (2017) National Oceanic and Atmospheric Administration. Available online at: https://climate.nasa.gov/vital-signs/carbon-dioxide/ (Accessed June $23,2017)$.

Noble, R. R., Stalker, L., Wakelin, S. A., Pejcic, B., Leybourne, M. I., Hortle, A. L., et al. (2012). Biological monitoring for carbon capture and storage-A review and potential future developments. Int. J. Greenh. Gas. Con. 10, 520-535. doi: 10.1016/j.ijggc.2012.07.022

Norici, A., Dalsass, A., and Giordano, M. (2002). Role of phosphoenolpyruvate carboxylase in anaplerosis in the green microalga Dunaliella salina cultured under different nitrogen regimes. Physiol. Plant. 116, 186-191. doi: 10.1034/j.1399-3054.2002.1160207.x

Olajire, A. A. (2010). $\mathrm{CO}_{2}$ capture and separation technologies for end-of-pipe application - a review. Energy 35, 2610-2628. doi: 10.1016/j.energy.2010.02.030

Onstott, T. C., Moser, D. P., Pfiffner, S. M., Fredrickson, J. K., Brockman, F. J., Phelps, T. J., et al. (2003). Indigenous and contaminant microbes in ultradeep mines. Environ. Microbiol. 5, 1168-1191. doi: 10.1046/j.1462-2920.2003.00512.x

Orr, J. F. M. (2009). $\mathrm{CO}_{2}$ capture and storage: are we ready? Energy Environ. Sci. 2, 449-458. doi: 10.1039/b822107n

Pala, N., Micheletto, L., Sechi, M., Aggarwal, M., Carta, F., McKenna, R., et al. (2014). Carbonic anhydrase inhibition with benzenesulfonamides and tetrafluorobenzenesulfonamides obtained via click chemistry. ACS Med. Chem. Lett. 5, 927-930. doi: 10.1021/ml500196t

Park, J. Y., Kim, Y. H., and Min, J. (2017). $\mathrm{CO}_{2}$ reduction and organic compounds production by photosynthetic bacteria with surface displayed carbonic anhydrase and inducible expression of phosphoenolpyruvate carboxylase. Enzym. Microb. Technol. 96, 103-110. doi: 10.1016/j.enzmictec.2016.1 0.005

Pastoreková, S., and Pastorek, J. (2004). "Cancer-related carbonic anhydrase isozymes and their inhibition" in Carbonic Anhydrase: Its Inhibitors and
Activators, eds A. Andrea Scozzafava, C. T. Supuran, and J. Conway (Boca Raton: CRC Press), 255-281.

Perry, R., and Gee, I. L. (1995). Vehicle emissions in relation to fuel composition. Sci. Total Environ. 169, 149-156. doi: 10.1016/0048-9697(95)04643-F

Pfaff, I., and Kather, A. (2009). Comparative thermodynamic analysis and integration issues of CCS steam powerplants based on oxy-combustion with cryogenic or membrane based air separation. Energy Procedia 1, 495-502. doi: 10.1016/j.egypro.2009.01.066

Power, I. M., Harrison, A. L., and Dipple, G. M. (2016). Accelerating mineral carbonation using carbonic anhydrase. Environ. Sci. Technol. 50, 2610-2618. doi: 10.1021/acs.est.5b04779

Prabhu, C., Wanjari, S., Gawande, S., Das, S., Labhsetwar, N., Kotwal, S., et al. (2009). Immobilization of carbonic anhydrase enriched microorganism on biopolymer based materials. J. Mol. Catal. B. Enzym. 60, 13-21. doi: 10.1016/j.molcatb.2009.02.022

Prabhu, C., Wanjari, S., Puri, A., Bhattacharya, A., Pujari, R., Yadav, R., et al. (2011). Region-specific bacterial carbonic anhydrase for biomimetic sequestration of carbon dioxide. Energy Fuels 25, 1327-1332. doi: 10.1021/ef101608r

Prasad, S., Khadatare, P. B., and Roy, I. (2011). Effect of chemical chaperones in improving the solubility of recombinant proteins in Escherichia coli. Appl. Environ. Microbiol. 77, 4603-4609. doi: 10.1128/AEM.05259-11

Princiotta, F. (2007). "The role of power generation technology in mitigating global climate change," in Challenges of Power Engineering and Environment, eds K. Cen, Y. Chi, and F. Wang (Berlin, Heidelberg: Springer), 3-13.

Puri, A. K., and Satyanarayana, T. (2010). "Enzyme and microbe mediated carbon sequestration" in $\mathrm{CO}_{2}$ Sequestration Technologies for Clean Energy, eds S. Z. Qasim and M. Goel (Delhi: Daya Publishing House), 119-129.

Ramanan, R., Kannan, K., Sivanesan, S. D., Mudliar, S., Kaur, S., Tripathi, A. K., et al. (2009). Bio-sequestration of carbon dioxide using carbonic anhydrase enzyme purified from Citrobacter freundii. World J. Microbiol. Biotechnol. 25, 981-987. doi: 10.1007/s11274-009-9975-8

Rayalu, S., Yadav, R., Wanjari, S., Prabhu, C., Mushnoori, S. C., Labhsetwar, N., et al. (2012). Nanobiocatalysts for carbon capture, sequestration and valorisation. Top. Catal. 55, 1217-1230. doi: 10.1007/s11244-012-9896-x

Reddy, K. J., Weber, H., Bhattacharya, P., Morris, A., Taylor, D., Christensen, M., et al. (2010). Instantaneous capture and mineralization of flue gas carbon dioxide: pilot scale study. Nat. Precedings. doi: 10.1038/npre.2010.5404.1

Reynolds, A. J., Verheyen, T. V., Adeloju, S. B., Meuleman, E., and Feron, P. (2012). Towards commercial scale post combustion capture of $\mathrm{CO}_{2}$ with monoethanolamine solvent: key considerations for solvent management and environmental impacts. Environ. Sci. Technol. 46, 3643-3654. doi: $10.1021 /$ es204051s

Rossi, M. (2014). A New Heat-Stable Carbonic Anhydrase and Uses Thereof. Patent WO $013064195 \mathrm{~A} 1$

Rout, G. R., and Das, P. (2003). Effect of metal toxicity on plant growth and metabolism: I. Zinc. Agronomie 23, 3-11. doi: 10.1051/agro:2002073

Russo, M. E., Scialla, S., De Luca, V., Capasso, C., Olivieri, G., and Marzocchella, A. (2013). Immobilization of carbonic anhydrase for biomimetic $\mathrm{CO}_{2}$ capture. Chem. Eng. Trans. 32, 1867-1872. doi: 10.3303/CET1332312

Sahdev, S., Khattar, S. K., and Saini, K. S. (2008). Production of active eukaryotic proteins through bacterial expression systems: a review of the existing biotechnology strategies. Mol. Cell. Biochem. 307, 249-264. doi: 10.1007/s11010-007-9603-6

Sakono, M., Kawashima, Y. M., Ichinose, H., Maruyama, T., Kamiya, N., and Goto, M. (2004). Direct refolding of inclusion bodies using reversed micelles. Biotechnol. Prog. 20, 1783-1787. doi: 10.1021/bp049887j

Salemme, F. R., and Weber, P. C. (2014). Engineered Carbonic Anhydrase Proteins for $\mathrm{CO}_{2}$ Scrubbing Applications. US 20140178962 A1.

Santos, A., Toledo-Fernandez, J. A., Mendoza-Serna, R., Gago-Duport, L., de la Rosa-Fox, N., Pinero, M., et al. (2007). Chemically active silica aerogelwollastonite composites for $\mathrm{CO} 2$ fixation by carbonation reactions. Ind. Eng. Chem. Res. 46, 103-107. doi: 10.1021/ie0609214

Satav, S. S., and Bhat, S., Thayumanavan, S. (2010). Feedback regulated drug delivery vehicles: carbon dioxide responsive cationic hydrogels for antidote release. Biomacromolecules 11, 1735-1740. doi: 10.1021/bm1005454

Seifritz, W. (1990). $\mathrm{CO}_{2}$ disposal by means of silicates. Nature 345:486 doi: $10.1038 / 345486 \mathrm{~b} 0$ 
Shahbazi, A., and Nasab, B. R. (2016). Carbon capture and storage (CCS) and its impacts on climate change and global warming. J. Pet. Environ. Biotechnol. 7:291. doi: 10.4172/2157-7463.1000291

Shakun, J. D., Clark, P. U., He, F., Marcott, S. A., Mix, A. C., Liu, Z., et al. (2012). Global warming preceded by increasing carbon dioxide concentrations during the last deglaciation. Nature 484, 49-54. doi: 10.1038/nature10915

Sharma, A., Bhattacharya, A., and Shrivastava, A. (2011). Biomimetic $\mathrm{CO}_{2}$ sequestration using purified carbonic anhydrase from indigenous bacterial strains immobilized on biopolymeric materials. Enzyme Microb. Technol. 48, 416-426. doi: 10.1016/j.enzmictec.2011.02.001

Shutova, T., Kenneweg, H., Buchta, J., Nikitina, J., Terentyev, V., Chernyshov, S., et al. (2008). The photosystem II_associated Cah3 in Chlamydomonas enhances the $\mathrm{O}_{2}$ evolution rate by proton removal. EMBO J. 27, 782-791. doi: 10.1038/emboj.2008.12

Silverman, D. N. (1982). Carbonic anhydrase: oxygen-18 exchange catalyzed by an enzyme with rate-contributing Proton-transfer steps. Meth. Enzymol. 87, 732-752. doi: 10.1016/S0076-6879(82)87037-7

Silverman, D. N., and Lindskog, S. (1988). The catalytic mechanism of carbonic anhydrase: implications of a rate-limiting protolysis of water. Acc. Chem. Res. 21, 30-36. doi: 10.1021/ar00145a005

Smith, K. S., and Ferry, J. G. (2000). Prokaryotic carbonic anhydrases. FEMS Microbiol. Rev. 24, 335-366. doi: 10.1111/j.1574-6976.2000.tb00546.x

Smith, K. S., Jakubzick, C., Whittam, T. S., and Ferry, J. G. (1999). Carbonic anhydrase is an ancient enzyme widespread in prokaryotes. Proc. Nat. Acad. Sci. U.S.A. 96, 15184-15189. doi: 10.1073/pnas.96.26.15184

So, A. K. C., Espie, G. S., Williams, E. B., Shively, J. M., Heinhorst, S., and Cannon, G. C. (2004). A novel evolutionary lineage of carbonic anhydrase ( $\varepsilon$ class) is a component of the carboxysome shell. J. Bacteriol. 186, 623-630. doi: $10.1128 / J B .186 .3 .623-630.2004$

So, A. K., van Spall, H. G. C., Coleman, J. R., and Espie, G. S. (1998). Catalytic exchange of $18 \mathrm{O}$ from $13 \mathrm{C} 18 \mathrm{O}$ labelled $\mathrm{CO}_{2}$ by wild type cells and ecaA, ecaB, and ccaA mutants of the cyanobacteria Synechococcus PCC7942 and Synechocystis PCC6803. Can. J. Bot. 76, 1153-1160. doi: 10.1139/b9 $8-063$

Soltes-Rak, E., Mulligan, M. E., and Coleman, J. R. (1997). Identification and characterization of gene encoding a vertebrate type carbonic anhydrase in cyanobacteria. J. Bacteriol. 179, 769-774. doi: 10.1128/jb.179.3.769-774. 1997

Soong, Y., Fauth, D. L., and Howard, B. H. (2006). $\mathrm{CO}_{2}$ sequestration with brine solution and fly ashes. Energy Convers. Manage. 47, 1676-1685. doi: 10.1016/j.enconman.2005.10.021

Srivastava, S., Bharti, R. K., Verma, P. K., and Thakur, I. S. (2015). Cloning and expression of gamma carbonic anhydrase from Serratia sp. ISTD04 for sequestration of carbon dioxide and formation of calcite. Biores. Technol. 188, 209-213. doi: 10.1016/j.biortech.2015.01.108

Stolaroff, J. K., Lowry, G. V., and Keith, D. W. (2005). Using CaO and $\mathrm{MgO}$ rich industrial waste streams for carbon sequestration. Energy Convers. Manage. 46, 687-699. doi: 10.1016/j.enconman.2004.05.009

Sugrue, M. F. (2000). Pharmacological and ocular hypotensive properties of topical carbonic anhydrase inhibitors. Prog. Retin. Eye. Res. 19, 87-112. doi: 10.1016/S1350-9462(99)00006-3

Supuran, C. T. (2008). Carbonic anhydrases: novel therapeutic applications for inhibitors and activators. Nat. Rev. Drug Disc. 7, 168-181. doi: 10.1038/nrd2467

Supuran, C. T. (2013). Carbonic anhydrases: from biomedical applications of the inhibitors and activators to biotechnological use for $\mathrm{CO}_{2}$ capture. J. Enzyme Inhib. Med. Chem. 28, 229-230. doi: 10.3109/14756366.2013.761876

Supuran, C. T. (2015). How many carbonic anhydrase inhibition mechanisms exist? J. Enzyme Inhib. Med. Chem. 31, 345-360. doi: 10.3109/14756366.2015.1122001

Supuran, C. T. (2016a). Drug interaction considerations in the therapeutic use of carbonic anhydrase inhibitors. Expert. Opin. Drug. Metab. Toxicol. 12, 423-431. doi: $10.1517 / 17425255.2016 .1154534$

Supuran, C. T. (2016b). Legionella pneumophila carbonic anhydrases: underexplored antibacterial drug targets. Pathogens 5:44. doi: $10.3390 /$ pathogens5020044

Supuran, C. T., Scozzafava, A., and Casii, A. (2003). Carbonic anhydrase inhibitors. Med. Res. Rev. 23, 146-189. doi: 10.1002/med.10025
Svensson, R., Odenberger, M., Johnsson, F., and Stromberg, L. (2004). Transportation systems for $\mathrm{CO}_{2}$ - application to carbon capture and storage. Energy Convers. Manage. 45, 2343-2353. doi: 10.1016/j.enconman.2003.11.022

Swartz, J. R. (2001). Advances in Escherichia coli production of therapeutic proteins. Curr. Opin. Biotechnol. 12, 195-201. doi: 10.1016/S0958-1669(00)00199-3

Tahirov, T. H., Oki, H., Tsukihara, T., Ogasahara, K., Yutani, K., Ogata, K., et al. (1998). Crystal structure of methionine aminopeptidase from hyperthermophile, Pyrococcus furiosus. J. Mol. Biol. 284, 101-124. doi: 10.1006/jmbi.1998.2146

Teicher, B. A., Liu, S. D., Liu, J. T., Holden, S. A., and Herman, T. S. (1992), A carbonic anhydrase inhibitor as a potential modulator of cancer therapies. Anticancer Res. 13, 1549-1556.

Thompson, R. B., and Jones, E. R. (1993). Enzyme-based fiber optic zinc biosensor. Anal. Chem. 65, 730-734. doi: 10.1021/ac00054a013

Thompson, R. B., Peterson, D., Mahoney, W., Cramer, M., Maliwal, B. P., Suh, S. W., et al. (2002). Fluorescent zinc indicators for neurobiology. J. Neurosci. Methods 118, 63-75. doi: 10.1016/S0165-0270(02)00144-9

Thompson, R. B., Whetsell, W. O. Jr., Maliwal, B. P., Fierke, C. A., and Frederickson, C. J. (2000). Fluorescence microscopy of stimulated Zn (II) release from organotypic cultures of mammalian hippocampus using a carbonic anhydrase-based biosensor system. J. Neurosci. Methods 96, 35-45. doi: 10.1016/S0165-0270(99)00183-1

Tobal, J. M., and Balieiro, M. E. (2014). Role of carbonic anhydrases in pathogenic micro-organisms: a focus on Aspergillus fumigatus. J. Med. Microbiol. 63, 15-27. doi: $10.1099 / \mathrm{jmm} .0 .064444-0$

Tripp, B. C., and Ferry, J. G. (2000). A structure- function study of a proton transport pathway in the $\gamma$-class carbonic anhydrase from Methanosarcina thermophila. Biochemistry 39, 9232-9240. doi: 10.1021/bi0001877

Tripp, B. C., Bell, C. B. III., Cruz, F., Krebs, C., and Ferry, J. G. (2004). A role for iron in an ancient carbonic anhydrase. J. Biol. Chem. 279, 6683-6687. doi: $10.1074 /$ jbc.M311648200

Tsouris, C., Aaron, D. S., and Williams, K. A. (2010). Is carbon capture and storage really needed? Environ. Sci. Technol. 44, 4042-4045. doi: 10.1021/es903626u

Tsumoto, K., Ejima, D., Kumagai, I., and Arakawa, T. (2003). Practical considerations in refolding proteins from inclusion bodies. Protein. Expr. Purif. 28, 1-8. doi: 10.1016/S1046-5928(02)00641-1

Umetsu, M., Tsumoto, K., Hara, M., Ashish, K., Goda, S., Adschiri, T., et al. (2003). How additives influence the refolding of immunoglobulin-folded proteins in a stepwise dialysis system spectroscopic evidence for highly efficient refolding of a single-chain fv fragment. J. Biol. Chem. 278, 8979-8987. doi: $10.1074 /$ jbc.M212247200

Valdivia, R. H., and Falkow, S. (1997). Fluorescence-based isolation of bacterial genes expressed within host cells. Science 277, 2007-2011. doi: $10.1126 /$ science.277.5334.2007

van de Vossenberg, J., Woebken, D., Maalcke, W. J., Wessels, H. J., Dutilh, B. E., Kartal, B., et al. (2003). The metagenome of the marine anammox bacterium 'Candidatus Scalindua profunda' illustrates the versatility of this globally important nitrogen cycle bacterium. Environ. Microbiol. 15, 1275-1289. doi: $10.1111 / j .1462-2920.2012 .02774 . x$

Vericella, J. J., Baker, S. E., Stolaroff, J. K., Duoss, E. B., Hardin, J. O. IV., Lewicki, J., et al. (2015). Encapsulated liquid sorbents for carbon dioxide capture. Nat. Commun. 6, 1-7. doi: 10.1038/ncomms7124

Vullo, D., De Luca, V., Scozzafava, A., Carginale, V., Rossi, M., Supuran, C. T., et al. (2012). Anion inhibition studies of the fastest carbonic anhydrase (CA) known, the extremo-CA from the bacterium Sulfurihydrogenibium azorense. Bioorg. Med. Chem. Lett. 22, 7142-7145. doi: 10.1016/j.bmcl.2012.09.065

Vullo, D., Nishimori, I., Minakuchi, T., Scozzafava, A., and Supuran, C. T. (2011). Inhibition studies with anions and small molecules of two novel $\beta$-carbonic anhydrases from the bacterial pathogen Salmonella enterica serovar typhimurium. Bioorg. Med. Chem. Lett. 21, 3591-3595. doi: 10.1016/j.bmcl.2011.04.105

Wall, T. F. (2007). Combustion processes for carbon capture. Proc. Combus. Instit. 31,31-47. doi: 10.1016/j.proci.2006.08.123

Wang, D., Hurst, T. K., Thompson, R. B., and Fierke, C. A. (2011). Genetically encoded ratiometric biosensors to measure intracellular exchangeable zinc in Escherichia coli. J. Biomed. Opt. 16, 087011-087011. doi: 10.1117/1.3613926 
Wanjari, S., Prabhu, C., Satyanarayana, T., Vinu, A., and Rayalu, S. (2012). Immobilization of carbonic anhydrase on mesoporous aluminosilicate for carbonation reaction. Micropor. Mesopor. Mat. 160, 151-158. doi: 10.1016/j.micromeso.2012.04.005

Wanjari, S., Prabhu, C., Yadav, R., Satyanarayana, T., Labhsteswar, N., and Rayalu, S. (2011). Immobilization of carbonic anhydrase on chitosan beads for enhanced carbonation reaction. Process Biochem. 46, 1010-1018. doi: 10.1016/j.procbio.2011.01.023

Williamson, S. J., Allen, L. Z., Lorenzi, H. A., Fadrosh, D. W., Brami, D., Thiagarajan, M., et al. (2012). Metagenomic exploration of viruses throughout the Indian Ocean. PLoS ONE 7:e42047. doi: 10.1371/journal.pone.0042047

Wilson, Z. E., and Brimble, M. A. (2009). Molecules derived from the extremes of life. Nat. Prod. Rep. 26, 44-71. doi: 10.1039/B800164M

Wood, H. G., Werkman, C. H., Hemingway, A., and Nier, A.O. (1941). Heavy carbon as a tracer in heterotrophic carbon dioxide assimilation. J. Biol. Chem. 139, 367-375.

Wulf, N. R., and Matuszewski, K. A. (2013). Sulfonamide cross-reactivity: is there evidence to support broad cross-allergenicity? Am. J. Health-Syst. Pharm. 70, 1483-1494. doi: 10.2146/ajhp120291

Xiao, L., Hao, J., Wang, W., Lian, B., Shang, G., Yang, Y., et al. (2014). The up-regulation of carbonic anhydrase genes of Bacillus mucilaginosus under soluble $\mathrm{Ca}^{2+}$ deficiency and the heterologously expressed enzyme promotes calcite dissolution. Geomicrobiol. J. 31, 632-641. doi: 10.1080/01490451.2014.8 84195

Xiao, L., Sun, Q., Yuan, H., Li, X., Chu, Y., Ruan, Y., et al. (2016). A feasible way to increase carbon sequestration by adding dolomite and $\mathrm{K}$ feldspar to soil. Cogent Geosci. 2:1205324. doi: 10.1080/23312041.2016.12 05324

Xu, J., Sun, J., Wang, Y., Sheng, J., Wang, F., and Sun, M. (2014). Application of iron magnetic nanoparticles in protein immobilization. Molecules 19, 11465-11486. doi: 10.3390/molecules190811465

Yadav, R. R., Mudliar, S. N., Shekh, A. Y., Fulke, A. B., Devi, S. S., Krishnamurthi, K., et al. (2012). Immobilization of carbonic anhydrase in alginate and its influence on transformation of $\mathrm{CO}_{2}$ to calcite. Process Biochem. 47, 585-590. doi: 10.1016/j.procbio.2011.12.017

Yadav, R., Satyanarayanan, T., Kotwal, S., and Rayalu, S. (2011). Enhanced carbonation reaction using chitosan-based carbonic anhydrase nanoparticles. Curr. Sci. 100, 520-524.

Yadav, R., Wanjari, S., Prabhu, C., Kumar, V., Labhsetwar, N., Satyanarayanan, T., et al. (2010). Immobilized carbonic anhydrase for the biomimetic carbonation reaction. Energy Fuels 24, 6198-6207. doi: 10.1021/ef100750y

Zhang, Z., Lian, B., Hou, W., Chen, M., Li, X., Shen, W., et al. (2011). Optimization of nutritional constituents for carbonic anhydrase production by Bacillus mucilaginosus K02. Afr. J. Biotechnol. 10, 8403-8413. doi: 10.5897/AJB10.1508

Zhi, W., Landry, S. J., Gierasch, L. M., and Srere, P. A. (1992). Renaturation of citrate synthase: influence of denaturant and folding assistants. Protein Sci. 1, 522-529. doi: 10.1002/pro.5560010407

Zimmerman, S., Innocenti, A., Casini, A., Ferry, J. G., Scozzafava, A., and Supuran, C. T. (2004). Carbonic anhydrase inhibitors. Inhibition of the prokariotic beta and gamma-class enzymes from Archaea with sulfonamides. Bioorg. Med. Chem. Lett. 14, 6001-6006. doi: 10.1016/j.bmcl.2004.09.085

Conflict of Interest Statement: The authors declare that the research was conducted in the absence of any commercial or financial relationships that could be construed as a potential conflict of interest.

The reviewer SD and handling Editor declared their shared affiliation, and the handling Editor states that the process nevertheless met the standards of a fair and objective review.

Copyright (C) 2017 Bose and Satyanarayana. This is an open-access article distributed under the terms of the Creative Commons Attribution License (CC BY). The use, distribution or reproduction in other forums is permitted, provided the original author(s) or licensor are credited and that the original publication in this journal is cited, in accordance with accepted academic practice. No use, distribution or reproduction is permitted which does not comply with these terms. 